\title{
A 250 ka oxygen isotope record from diatoms at Lake El'gygytgyn, far east Russian Arctic
}

\author{
B. Chapligin ${ }^{1}$, H. Meyer ${ }^{1}$, G. E. A. Swann ${ }^{2}$, C. Meyer-Jacob ${ }^{3}$, and H.-W. Hubberten ${ }^{1}$ \\ ${ }^{1}$ Alfred Wegener Institute for Polar and Marine Research, Research Unit Potsdam, Telegrafenberg A43, \\ 14473 Potsdam, Germany \\ ${ }^{2}$ School of Geography, University of Nottingham, University Park, Nottingham, NG7 2RD, UK \\ ${ }^{3}$ Department of Ecology and Environmental Science, Umeå University, 90187 Umeå, Sweden
}

Correspondence to: B. Chapligin (bernhard.chapligin@awi.de)

Received: 26 March 2012 - Published in Clim. Past Discuss.: 11 April 2012

Revised: 10 September 2012 - Accepted: 13 September 2012 - Published: 17 October 2012

Abstract. In 2003 sediment core Lz1024 was drilled at Lake El'gygytgyn, far east Russian Arctic, in an area of the Northern Hemisphere which has not been glaciated for the last 3.6 Ma. Biogenic silica was used for analysing the oxygen isotope composition $\left(\delta^{18} \mathrm{O}_{\text {diatom }}\right)$ in the upper $13 \mathrm{~m}$ long section dating back about $250 \mathrm{ka}$ with samples dominated by one taxa in the $<10 \mu \mathrm{m}$ fraction (Cyclotella ocellata). Downcore variations in $\delta^{18} \mathrm{O}$ values show that glacial-interglacial cycles are present throughout the core and $\delta^{18} \mathrm{O}_{\text {diatom-values }}$ are mainly controlled by $\delta^{18} \mathrm{O}_{\text {precipitation. Changes reflect the }}$ Holocene Thermal Maximum, the Last Glacial Maximum (LGM) and the interglacial periods corresponding to MIS 5.5 and MIS 7 with a peak-to-peak amplitude between LGM and MIS 5.5 of $\Delta^{18} \mathrm{O}=5.3 \%$. This corresponds to a mean annual air temperature difference of about $9^{\circ} \mathrm{C}$. Our record is the first continuous $\delta^{18} \mathrm{O}_{\text {diatom }}$ record from an Arctic lake sediment core directly responding to precipitation and dating back more than $250 \mathrm{ka}$ and correlates well with the stacked marine $\delta^{18}$ O LR0 $4(r=0.58)$ and $\delta$ D EPICA Dome$\mathrm{C}$ record $(r=0.69)$. With $\delta^{18} \mathrm{O}$ results indicating strong links to both marine and ice-core records, records from Lake El'gygytgyn can be used to further investigate the sensitivity of the Arctic climate to both past and future global climatic changes.

\section{Introduction}

\subsection{The Arctic as an important area for paleoclimate reconstruction}

The Arctic experienced the most rapid warming in the last $150 \mathrm{yr}$ (Serreze et al., 2000; Kaufman et al., 2009; Bekryaev et al., 2010) with a continuation of this temperature trend above the global average projected for the 21st century (Serreze et al., 2000; Anisimov et al., 2007). Especially in climate-sensitive areas such as the Arctic (Serreze and Francis, 2006a, b; Miller et al., 2010; Serreze and Barry, 2011), longer, continuous terrestrial records for paleo-climate reconstructions are rare (Brigham-Grette et al., 2007; CCSP, 2009) due to the coverage of large areas by glaciers, e.g. during the Last Glacial Maximum (LGM) (Dyke and Prest, 1987; Lehman et al., 1991; Thiede, 2004), which destroyed sedimentary sequences in lakes especially in the western part of Siberia (Svendsen et al., 1999; Hubberten et al., 2004). The Beringia land bridge which connected Alaska (eastern Beringia) and northeast Russia (western Beringia) was exposed during the glacials (Hopkins, 1967; Hopkins et al., 1982; Brigham-Grette, 2001) linked to a eustatic sea-level drop due to growing ice caps. However, due to its dry climate the Eastern Arctic experienced only valley glaciation (Glushkova, 2001) and the precipitation-controlled eastern margin of the Eurasian Ice Sheet never extended to Eastern Siberia (Svendsen et al., 2004; Melles et al., 2007).

Lake sediments are known as excellent archives for the reconstruction of past climate and environmental changes which may provide insights as to how regions may respond 
to future change. The longest lacustrine palaeoenvironmental record in Siberia exists from Lake Baikal, reaching back to 35 Mio years before present (Tapponnier and Molnar, 1979). However, Lake Baikal is located south of the Arctic circle with southern catchments having generally higher $\delta^{18} \mathrm{O}$ values due to lower proportion of snowmelt (e.g. Seal and Shanks, 1998). Though the majority of precipitation to this region comes via the westerlies (Kurita et al., 2004), the climate is increasingly influenced by south and southeast cyclones in July and August (Bezrukova et al., 2008; Kostrova et al., 2012). In an attempt to obtain Quaternary lake records from the terrestrial, far east Russian Arctic drilling campaigns were conducted at Lake El'gygytgyn in an area of the Northern Hemisphere which has not been glaciated during at least the last five glacial/interglacial cycles and has the potential to be an archive of continuous and undisturbed sedimentation (Brigham-Grette et al., 2007; Melles et al., 2007).

\subsection{The importance of $\delta^{18} \mathrm{O}_{(\text {diatom })}$ records}

Oxygen isotope records from ice-cores (Greenland-Ice-CoreProject members, 1993; Grootes et al., 1993; Petit et al., 1999; EPICA members, 2004 and 2006) or carbonate organisms (Zachos et al., 2001; Lisiecki and Raymo, 2005) are amongst the most important proxies for reconstructing paleoenvironmental conditions and paleoclimate. In regions of high latitude where ice-records are not available or where carbonates are absent, as is the case for Beringia and Lake El'gygytgyn, the oxygen isotope composition from lacustrine biogenic silica, i. e. diatoms, often represents the best isotope proxy for reconstructing past climate changes (Shemesh et al., 2001; Leng and Marshall, 2004). This is similar for $\delta^{18} \mathrm{O}$ records from marine biogenic silica in regions of the ocean floor void of carbonate (Shemesh et al., 1992). By taking potential controls and effects into account, the analysis of oxygen isotopes in lacustrine biogenic silica provides one of the rare opportunities to gain a direct and continuous $\delta^{18} \mathrm{O}$ signal from paleo-precipitation beyond the LGM in the Eastern Arctic. This can then be compared with other regional and global $\delta^{18} \mathrm{O}$ records to better understand the links between West Beringia and the wider global climate system. The preparation of the samples (e.g. JuilletLeclerc and Labeyrie, 1987; Shemesh et al., 1995; Morley et al., 2004), contamination assessment (Lamb et al., 2007; Brewer et al., 2008; Mackay et al., 2011; Swann and Patwardhan, 2011) as well as the oxygen isotope analysis for diatoms are often challenging and time-consuming (Leng and Barker, 2006; Swann and Leng, 2009). Recently, improved protocols have been developed for the purification of small fractions and a more reliable contamination correction (Chapligin et al., 2012). In addition, a faster dehydration and analytical technique has also been introduced (Chapligin et al., 2010). However, when analysing 250 ka old material, diagenetic changes pose a serious threat to the reliability of $\delta^{18} \mathrm{O}$-values from biogenic silica. Additionally, the species-effect on isotope fractionation is still not well understood for diatoms but this effect was not observed for the prevailing diatom species in sub-surface samples ( 2 to $4 \mathrm{~cm}$ ) at Lake El'gygytgyn (Chapligin et al., 2012).

This study aims to analyse the upper $13 \mathrm{~m}$ sequence of a sediment core from Lake El'gygytgyn and provide a continuous, $250 \mathrm{ka} \delta^{18} \mathrm{O}$ record from diatoms for the terrestrial Eastern Arctic. Additionally, potential diagenetic changes and their impact on the oxygen isotope composition are addressed.

\section{Materials and methods}

\subsection{Site description, material and age model}

Lake El'gygytgyn is located in the far east Russian Arctic $\left(67^{\circ} 30^{\prime} \mathrm{N}, 172^{\circ} 05^{\prime} \mathrm{E}\right)$ at $492 \mathrm{~m}$ a.s.l. (Fig. 1a) inside a crater structure formed by a meteorite impact circa 3.6 Ma ago (Layer, 2000). The lake is of circular shape, about $12 \mathrm{~km}$ in diameter, $170 \mathrm{~m}$ deep, cold-monomictic and ultra-oligotrophic (Nolan and Brigham-Grette, 2007). Fifty streams drain into the lake, the Enmyvaam River is the only outflow in the southeast of the lake and the total catchment area is $293 \mathrm{~km}^{2}$ (Nolan and Brigham-Grette, 2007).

Several cores have been drilled in the last decade (Fig. 1b), including the $16.5 \mathrm{~m}$ core Lz1024 drilled in 2003 $\left(67^{\circ} 30.13^{\prime} \mathrm{N} ; 172^{\circ} 06.46^{\prime} \mathrm{E}\right)$ examined in this study. A gravity corer (UWITEC Corp., Austria) was used for the watersediment transition and changed to a percussion piston corer further down the sediment (Melles et al., 2005). In total, 96 samples spread over the first $13 \mathrm{~m}$ were chosen for analysis, covering the last three glacial-interglacial cycles. From $2 \mathrm{~cm}$ sections, sub-samples with average dry weight of $1.9 \mathrm{~g}$ were taken. As the first test series of 10 samples distributed equidistantly downcore did not provide enough material after purification, two subsequent samples were merged and the average age and depth determined. The first age model for core Lz1024 was proposed by Juschus et al. (2007), using isochronous sediment layers and susceptibility variations to correlate core Lz1024 to the previously dated $13.5 \mathrm{~m}$ core PG1351 with the final age model, and then revised after tuning the magnetic susceptibility to the insolation at $70^{\circ} \mathrm{N}$ (Nowaczyk et al., 2002, 2007). The core base of Lz1024 was dated to a maximum age of $350 \mathrm{ka}$ (Frank et al., 2012; age model for composite profile from ICDP Site 5011-1 in Melles et al., 2012); the focus of this study is on the record of the first $250 \mathrm{ka}$.

\subsection{Methods}

\subsubsection{Preparation}

Various steps are essential from coring to the final interpretation of the oxygen isotope composition from biogenic silica (overview in Fig. 2). One taxa dominates the diatom 
(a)

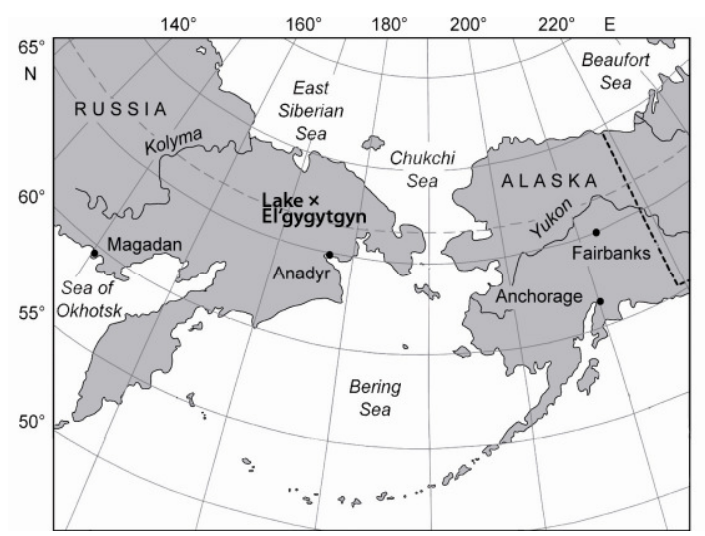

(b)

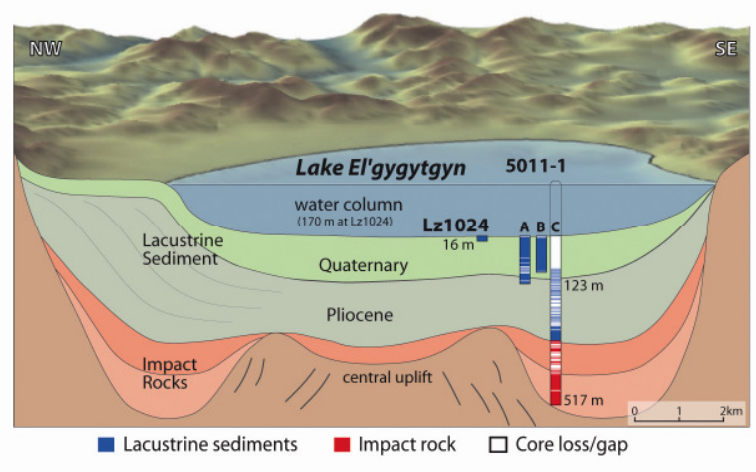

Fig. 1. (a) Geographical position of Lake El'gygytgyn and (b) drilling locations (Melles et al., 2011).

assemblage at Lake El'gygytgyn in the investigated first $250 \mathrm{ka}$ : Cyclotella ocellata (avg. size 5-10 $\mu \mathrm{m}, 95$ to $100 \%$ relative abundance) with minor occurrences of Pliocaenicus seczkinae (avg. size $20-35 \mu \mathrm{m}, 0-5 \%$, relative abundance) (Cremer et al., 2005; Cherapanova et al., 2007; Snyder et al., 2012). For this reason, the normally analysed $>10 \mu \mathrm{m}$ fraction did not provide enough diatom material for oxygen isotope analyses in most core sections. Consequently, in an attempt to obtain an isotope record dominated by a single taxa, the $<10 \mu \mathrm{m}$ fraction was purified according to an 8 -step method developed by Chapligin et al. (2012) which is similar to the 4-step method (Morley et al., 2004). After freeze-drying, the samples were treated with $\mathrm{H}_{2} \mathrm{O}_{2}(32 \%)$ and $\mathrm{HCl}(10 \%)$ to remove organic matter and carbonates and wet sieved into $<10 \mu \mathrm{m}$ and $>10 \mu \mathrm{m}$ fractions. Four multiple heavy liquid separation (HLS) steps with varying densities (from 2.25 to $2.15 \mathrm{~g} \mathrm{~cm}^{-3}$ ) were then applied using a sodium polytungstate (SPT) solution before being exposed to a mixture of $\mathrm{HClO}_{4}(65 \%)$ and $\mathrm{HNO}_{3}(65 \%)$ for removing any remaining micro-organics.

\subsubsection{Species assessment}

The diatom assemblage in the $<10 \mu \mathrm{m}$ fraction of 40 purified samples equally distributed throughout the core was assessed by counting under light microscope (LM) (Chapligin et al., 2012, based on Morley et al., 2004, and Swann et al., 2008). Five random fields of view were selected along a transect in the middle of the slide and at least 200 valves as well as fragments were counted whenever possible. The biovolume was calculated by defining average area-sizes (Chapligin et al., 2012) for each species as it better reflects the actual proportion of each taxa when analysing for oxygen isotopes than using the number of valves.

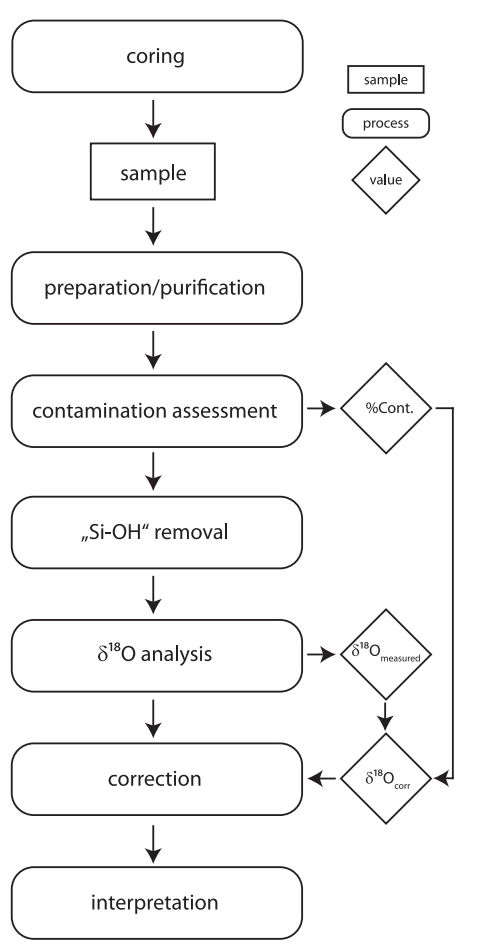

Fig. 2. Method outline from coring to final interpretation.

\subsubsection{FTIR analysis}

The question of potential diagenetic changes and their impact on the oxygen isotope composition in the amorphous structure was addressed by performing diffuse reflectance Fourier Transform Infrared Spectroscopy (FTIRS) at Umeå University, Sweden. This method determines individual compounds in biogenic silica by recording the different characteristic vibration patterns (absorption peaks) of the chemical bonds present in the structure (siloxane bonds: $\mathrm{Si}-\mathrm{O}-\mathrm{Si}$; 
silanol bonds: $\mathrm{Si}-\mathrm{OH} ; \mathrm{H}_{2} \mathrm{O}$ ) over a certain wavelength window (Schmidt et al., 2001; Gendron-Badou et al., 2003; Moschen et al., 2006; Leng et al., 2009; Swann and Patwardhan, 2011). A relative reduction in $\mathrm{Si}-\mathrm{OH}$ groups compared to the $\mathrm{Si}-\mathrm{O}-\mathrm{Si}$ groups indicates a diagenetic change by a condensation reaction $\left(\mathrm{Si}-\mathrm{OH}+\mathrm{HO}-\mathrm{Si} \rightarrow \mathrm{Si}-\mathrm{O}-\mathrm{Si}+\mathrm{H}_{2} \mathrm{O}\right.$ ) typical for an alteration of amorphous silica by temperature and/or pressure towards a higher state of organisation. An FTIR spectrometer (Bruker IFS 66v/S) equipped with a diffuse reflectance accessory (Harrick Inc.) was used with $11 \mathrm{mg}$ of sample material mixed with $500 \mathrm{mg} \mathrm{KBr}$ for the analysis under vacuum (4 mbar) conditions (Vogel et al., 2008; Rosén et al., 2010). Sixteen (16) purified diatom samples from different core depths (first sample at $0.09 \mathrm{~m}$, last sample at $12.35 \mathrm{~m}$ ) were selected and scanned (64 scans per sample) with measurements taken every $4 \mathrm{~cm}^{-1}$ for the spectral region between 3750 and $400 \mathrm{~cm}^{-1}$.

All wavelength absorption peaks $>1500 \mathrm{~cm}^{-1}$ were removed as these peaks are not related to biogenic silica (Fröhlich, 1989) or linked to molecular vibrations of hydroxide (-OH stretching). Focusing on wavelengths $<1500 \mathrm{~cm}^{-1}$ allows only the silica bonds from the diatom frustules to be examined. Common peak centres for amorphous silica are $450 \mathrm{~cm}^{-1}, 800 \mathrm{~cm}^{-1}$ and $1100 \mathrm{~cm}^{-1}$ for various modes of siloxane bonds and $945 \mathrm{~cm}^{-1}$ for silanol bonds (GendronBadou et al., 2003; Swann and Patwardhan, 2011). In our study the data was baseline-corrected and normalised, so that the area under each curve adds up to $100 \%$, with individual peaks separated by applying a Gaussian peak fitting (Fig. 4a) (Swann and Patwardhan, 2011) using the software Fytik, Version 0.9.3 (http://fityk.nieto.pl/). Peak types were then assigned ( $\mathrm{Si}-\mathrm{OH}$ and $\mathrm{Si}-\mathrm{O}-\mathrm{Si}$ ) and the percentages calculated from the respective areas.

However, when using FTIR each $\mathrm{Si}-\mathrm{O}-\mathrm{Si}$ band has its own "sensitivity", so absolute unweighted calculations are not suitable for comparing individual samples. Therefore, the relative change in $\mathrm{Si}-\mathrm{OH}$ bond determined by a single peak, was calculated. The highest peak area (top sample at $0.09 \mathrm{~m}$, $1.3 \mathrm{ka}$ ) was set at $100 \%$ (using the size of the un-normalised -Si-OH peak following peak fitting).

\subsubsection{Isotope analysis}

Oxygen isotope analysis was performed with a PDZ Europa 2020 mass spectrometer (MS-2020; now supplied by Sercon Ltd., UK) following the method of Chapligin et al. (2010). Prior to isotope analyses, hydrous groups $\left(\mathrm{H}_{2} \mathrm{O}\right.$, $-\mathrm{OH})$ were removed from an initial sample weight of 1.5 to $2 \mathrm{mg}$ using ramp degassing under inert gas flow conditions (inert Gas Flow Dehydration =iGFD technique) in a horizontal ceramic tube furnace flushed with helium (Chapligin et al., 2010). The dehydrated sample was then reacted by laser fluorination under $\mathrm{BrF}_{5}$ atmosphere to liberate $\mathrm{O}_{2}$ based on Sharp (1990). The oxygen was separated of byproducts and directed to the mass spectrometer for isotope analysis. Every fifth sample was a biogenic working standard to verify the quality of the analyses. For this, the biogenic standard BFC (Leng et al., 2001; Leng and Sloane, 2008; Chapligin et al., 2010) calibrated within an inter-laboratory comparison was used (Chapligin et al., 2011). With $\delta^{18} \mathrm{O}-$ values of $+29.0 \pm 0.3 \%$, BFC is the closest diatom working standard to the Lake El'gygytgyn samples $\left(\delta^{18} \mathrm{O}\right.$-values range between +19 and $+26 \%$ ) available. Additionally, the international quartz standard NBS28 $\left(\delta^{18} \mathrm{O}=+9.57 \%\right.$; Hut, 1987; Gröning et al., 2007) was measured. Long-term standard measurements of $\delta^{18} \mathrm{O}$-values in silica show standard deviations of $1 \sigma=0.15 \%$ for quartz and $1 \sigma \leq 0.25 \%$ for biogenic silica working standards such as BFC (Chapligin et al., 2010). Replicate isotope analyses were performed for 49 samples from the core Lz1024, which show a mean standard deviation of $0.13 \%$ ( $1 \sigma$, ranging between $0.00-0.41 \%$ ).

\subsubsection{Contamination assessment and correction technique}

The measured oxygen isotope composition $\left(\delta^{18} \mathrm{O}_{\text {measured }}\right)$ was corrected (to $\delta^{18} \mathrm{O}_{\text {corr }}$ ) using geochemical massbalancing (Brewer et al., 2008; improved by Swann and Leng, 2009; Chapligin et al., 2012).

$\delta^{18} \mathrm{O}_{\text {corr }}=\left(\delta^{18} \mathrm{O}_{\text {measured }}-\%\right.$ cont. $\left.\cdot \delta^{18} \mathrm{O}_{\text {cont. }}\right) / \%$ purity

where the percentage of purity was $100 \%$ subtracted by the percentage of remaining contamination (\% cont.). Determining $\%$ cont. by counting contamination particles/diatoms under a light microscope underestimates this parameter in the $<10 \mu \mathrm{m}$ fraction due to the presence of small, diffuse clay and silt particles (Chapligin et al., 2012). Thus, $\%$ cont. was calculated by dividing the sample percentage of $\mathrm{Al}_{2} \mathrm{O}_{3}$ by the $\mathrm{Al}_{2} \mathrm{O}_{3}$ percentage from a $100 \%$ contamination end member according to Brewer et al. (2008), Swann and Leng (2008) and Mackay et al. (2011). Chapligin et al. (2012) tested different contamination assessment techniques to Lake El'gygytgyn sub-surface samples and found no significant difference between this method and calculating $\%$ cont. by multiplying the sample's $\mathrm{Al}_{2} \mathrm{O}_{3}$ percentage with a clay assemblage factor that depends on the $\mathrm{Al}_{2} \mathrm{O}_{3}$ percentage of the average clay types present in the core. Hence, the $\mathrm{Al}_{2} \mathrm{O}_{3}$ percentage for each sample was analysed by EnergyDispersive X-ray Spectroscopy (EDS) (3-5 repetitions, diameter of excited-area size: $100-120 \mu \mathrm{m})$ and the $\%$ cont. and $\delta^{18} \mathrm{O}_{\text {cont. }}$ end-members determined from a heavy fraction after the first heavy liquid separation containing no diatoms (verified under scanning-electron microscope (SEM)), resulting in $\mathrm{Al}_{2} \mathrm{O}_{3}<10 \mu \mathrm{m}=16.6 \%$ and $\delta^{18} \mathrm{O}_{\text {cont. }}=+6.5 \%$ o (Chapligin et al., 2012). 


\section{Results}

\subsection{Diatom assemblage}

Five different types of diatoms and particles were counted for 40 samples downcore (Cyclotella ocellata, Pliocaenicus seczkinae, Surirella fragments, contamination particles and other diatom species) with an average of $236 \pm 57$ counts. The diatom assemblage in the analysed $<10 \mu \mathrm{m}$ fraction was almost mono-specific (Fig. 3, biovolume [\%] with Cyclotella ocellata constituting $>90 \%$ of all diatom biovolume in 37 out of 40 samples, and 70-90\% in 3 samples). The usually $>10 \mu \mathrm{m}$ sized species Pliocaenicus seczkinae occurs in the $<10 \mu \mathrm{m}$ fraction (smaller frustules) only in the first $70 \mathrm{~cm}$ of the record (about $9 \mathrm{ka}$ ) with biovolume abundances of up to $20 \%$. In the deeper core sections between $6 \mathrm{~m}$ and $10 \mathrm{~m}$ depth, Surirella fragments and other species have biovolume abundances of up to $15 \%$.

\subsection{Diagenetic effects}

In order to test the samples for diagenetic effects which could potentially alter $\delta^{18} \mathrm{O}$-values with time, FTIRS measurements were performed. The determined absolute percentage of $\mathrm{Si}-\mathrm{OH}$ bonds ranges between 5.6 and $9.0 \%$. As absolute unweighted calculations are not suitable for comparing individual samples, the change in $\mathrm{Si}-\mathrm{OH}$ bond percentages relative to the highest peak area (top sample at $0.09 \mathrm{~m}, 1.3 \mathrm{ka}$ set at $100 \%$ ) was calculated, resulting in maximum values in the upper core section between 0-30 ka (average 88\%), a local minimum at $90 \mathrm{ka}(64 \%)$ and relatively constant values further downcore (average for the period between $90 \mathrm{ka}$ and $230 \mathrm{ka}=68 \%$ ). A relative decrease of $2.9 \%$ per $10 \mathrm{ka}$ is observed in the first $90 \mathrm{ka}$ (total decrease of $26 \%$ ) with a correlation between $\mathrm{Si}-\mathrm{OH}$ percentage and age of $r^{2}=0.63$ ). For the relatively constant part of the $\mathrm{Si}-\mathrm{OH}$ percentage record from $90 \mathrm{ka}$ to $231 \mathrm{ka}$, only a weak correlation exists $\left(r^{2}=0.30\right)$. These numbers are not absolute and should only be used qualitatively to separate larger from smaller $\mathrm{Si}-\mathrm{OH}$ layers. However, different calculations by peak height ratio $\left(945 \mathrm{~cm}^{-1}(\mathrm{SiOH})\right.$ vs. $800 \mathrm{~cm}^{-1}$ (inter-tetrahedral Si-O-Si bending vibrations)) or peak area ratio $\left(990-860 \mathrm{~cm}^{-1}\right.$ vs. $860-750 \mathrm{~cm}^{-1}$ ) confirmed this trend.

\subsection{Contamination assessment and correction}

Out of 96 samples, 80 contained sufficient material after all purification steps for both oxygen isotope measurements and contamination analysis $(>5 \mathrm{mg}$ ). Chapligin et al. (2012) showed that the geochemical mass-balancing correction technique is reasonable for samples containing up to $2.5 \% \mathrm{Al}_{2} \mathrm{O}_{3}$ EDS or $<15 \%$ contamination. From the 80 analysed samples, 76 samples had an average $\mathrm{Al}_{2} \mathrm{O}_{3}$ percentage of $0.94 \pm 0.16 \%$ (Fig. 3, $\mathrm{SiO}_{2}$ and $\mathrm{Al}_{2} \mathrm{O}_{3}$ [\%], $\left.\Delta^{18} \mathrm{O}_{\text {corr-measured }}\right)$. For four samples the $\mathrm{Al}_{2} \mathrm{O}_{3}$ percentage was $>2.5 \%$ and for one more sample the $\mathrm{Al}_{2} \mathrm{O}_{3}$ percentage of $2.3 \%$ resulted in a high $\delta^{18} \mathrm{O}$-value correction of $>2.5 \%$. These samples were discarded from further interpretations.

Only a low correlation exists between the final mass of the sample after purification and $\mathrm{Al}_{2} \mathrm{O}_{3}$ percentage $\left(r^{2}=0.14\right)$. However, all samples above $2.5 \% \mathrm{Al}_{2} \mathrm{O}_{3}$ had final masses below $10 \mathrm{mg}$, which indicates that in horizons with low biogenic productivity $(\mathrm{BSi}<10 \%)$ a purification resulting in enough cleaned sample material can be rather difficult.

\section{$3.4 \delta^{18} \mathrm{O}_{\text {diatom }}$ record}

The $\delta^{18} \mathrm{O}_{\text {corr }}$-values (henceforth simplified again to $\delta^{18} \mathrm{O}$ ) throughout the $250 \mathrm{ka}$ record range between +19.1 and $+24.4 \%$ o with an average of $+21.7 \%$ o (Fig. 3). The first sample $(5 \mathrm{~cm}$ depth corresponding to $0.8 \mathrm{ka})$ shows a $\delta^{18} \mathrm{O}$-value of $+21.4 \%$, which is in good agreement with undated but younger sub-surface samples (Lz1032, 2$4 \mathrm{~cm}, \delta^{18} \mathrm{O}=+20.8 \%$ o) close to the Lz1024 drilling position (Chapligin et al., 2012). An increase to peak values of $+23.1 \%$ ( $0.52 \mathrm{~m}$ depth, corresponding to $6.6 \mathrm{ka})$ and $+23.4 \%$ o $(0.64 \mathrm{~m}, 8.4 \mathrm{ka})$ with a single spike of $+23.9 \%$ o $(1.18 \mathrm{~m}, 15.0 \mathrm{ka})$ is observed. This is followed downcore by a significant decline to an absolute minimum in $\delta^{18} \mathrm{O}$ of $+19.1 \%$ at $1.61 \mathrm{~m} / 23.1 \mathrm{ka}$. The $\delta^{18} \mathrm{O}$-values continuously increase until $+22.4 \%$ o (1.98 m, $34.3 \mathrm{ka})$, with subsequent fluctuations within about $1.0 \%$ or the next $70 \mathrm{ka}$, and prominent minima of $+19.6 \%$ ( $3.36 \mathrm{~m}, 70.5 \mathrm{ka})$ and $+20.0 \%$ o $(4.80 \mathrm{~m}, 107.3 \mathrm{ka})$ and average maxima with peaks of $+23.3 \%$ \% $(2.42 \mathrm{~m}, 54.6 \mathrm{ka})$ and $+21.0 \%$ o $(\sim 4.5 \mathrm{~m}, \sim$ $100 \mathrm{ka})$.

Measurements reveal an increase for the next $20 \mathrm{ka}$ with a peak of $+24.4 \%$ o $(5.85 \mathrm{~m}, 127.2 \mathrm{ka})$ before a progressive decrease down to $+20.7 \%$ o $(7.35 \mathrm{~m}, 162.2 \mathrm{ka})$. This peak at $5.85 \mathrm{~m}(127.2 \mathrm{ka})$ is the absolute maximum of the record. Between $7.35 \mathrm{~m}$ and $9.56 \mathrm{~m}(162.2 \mathrm{ka}$ and $187.6 \mathrm{ka})$, no further measurements could be performed as two more samples within this period did not provide sufficient material. The $\delta^{18} \mathrm{O}$-value of $+20.1 \%$ at $9.56 \mathrm{~m}$ (187.6 ka) supports the decreasing trend. From the short-term minimum downcore a rapid increase until $197.6 \mathrm{ka}$ was observed, plateauing until $209.3 \mathrm{ka}$ with an average $\delta^{18} \mathrm{O}=+23.2 \%$. Further downcore, a slight decline of $1.5 \%$ was detected until values increased again to a maximum of $+23.6 \%$ o (244.0 ka).

\section{Discussion}

\section{1 $\delta^{18} \mathrm{O}$ Isotope controls}

\subsubsection{Diagenetic alteration}

Diagenetic effects could severely influence the oxygen isotope composition on longer time scales by preferentially incorporating ${ }^{18} \mathrm{O}$ from exchangeable $\mathrm{Si}-\mathrm{OH}$ bonds into the $\mathrm{Si}-\mathrm{O}-\mathrm{Si}$ structure, resulting in higher $\delta^{18} \mathrm{O}$-values (Brandriss et al., 1998; Schmidt et al., 2001; Moschen et al., 
(a)

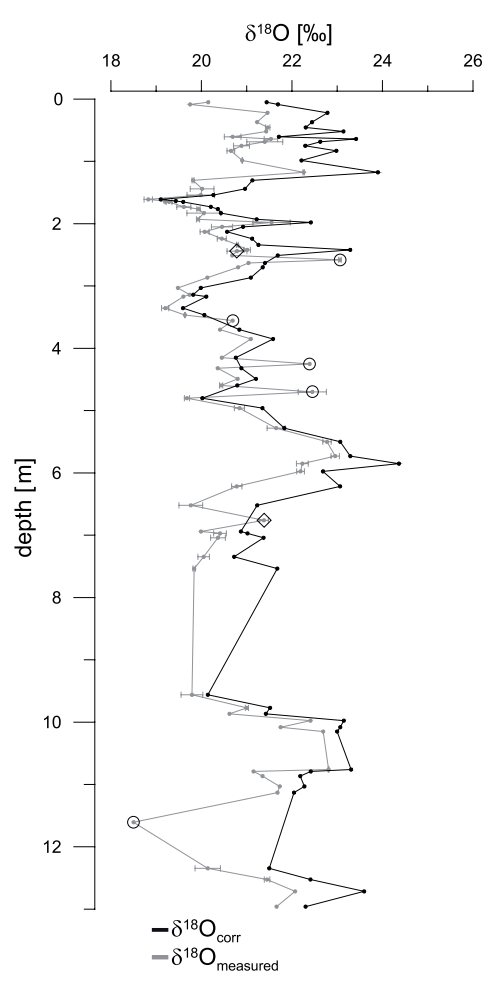

(b)

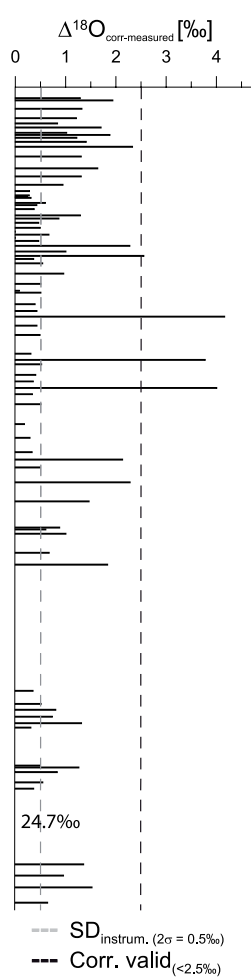

(c)

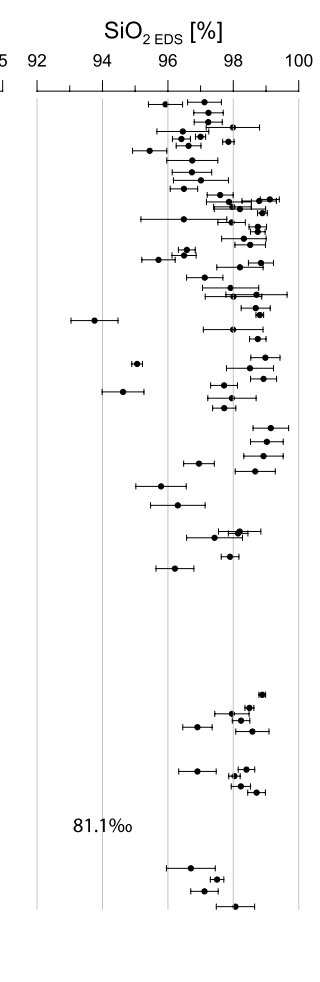

(d)

$\mathrm{Al}_{2} \mathrm{O}_{3 \text { EDS }}[\%]$

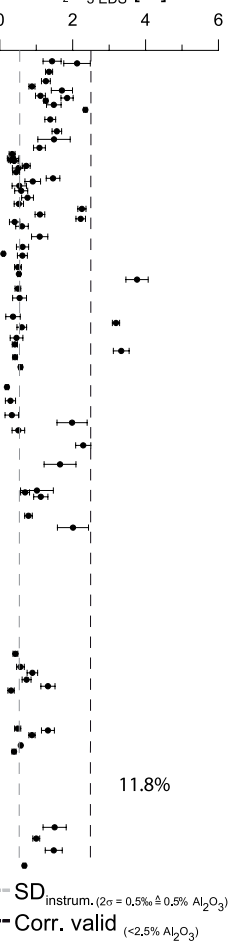

(e)

Biovolume [\%]

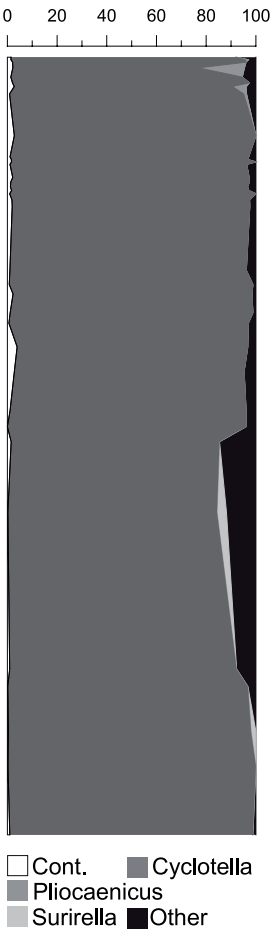

Fig. 3. (a) Uncorrected (grey) and corrected (black) $\delta^{18} \mathrm{O}$ record from the $<10 \mu \mathrm{m}$ fraction. Highly contaminated samples (encircled) or samples without correction data (open diamonds) were excluded. (b) A correction was performed according to $\mathrm{Al}_{2} \mathrm{O}_{3}$ percentages and the difference between measured and corrected $\delta{ }^{18} \mathrm{O}$-values displayed. (c) $\mathrm{SiO}_{2}$ percentages and (d) $\mathrm{Al}_{2} \mathrm{O}_{3}$ percentage of the sample analysed by EDS. (e) Five different categories (Contamination particles, different species) were counted for 40 samples and expressed in biovolume $[\%]$.

2006). Despite the relative decrease of silanol bonds of $0.6 \% / 10 \mathrm{ka}$ and a total of $20 \%$ for the whole $250 \mathrm{ka}$ record (Fig. 4b; top sample: $9 \mathrm{~cm}, 1.4 \mathrm{ka}, 100 \%$; deepest sample: $12.35 \mathrm{~m}, 231 \mathrm{ka}, 76 \%$ ), no general trend in the oxygen isotope composition of the samples $\left(+0.2 \%\right.$ o/ $\left.100 \mathrm{ka}, r^{2}=0.03\right)$ towards higher $\delta^{18} \mathrm{O}$-values could be detected in the $250 \mathrm{ka}$ record (Fig. 3). A rapid signal alteration (early stage diagenesis, Moschen et al., 2006) during sedimentation cannot be excluded. By this process, the $\delta^{18} \mathrm{O}_{\text {diatom-values would }}$ then reflect the deeper $\delta^{18} \mathrm{O}_{\text {lake water. However, for Lake }}$ El'gygytgyn this is unlikely as the lake is well-mixed and no significant differences in $\delta^{18} \mathrm{O}_{\text {lake water }}$ in the water profile can be observed (Chapligin et al., 2012). Hence, the results support the theory from Moschen et al. (2006) that any rapid signal alteration during sedimentation is followed by only minor post-sedimentary diagenetic changes, which are not detectable in the $\delta^{18} \mathrm{O}$ data. This makes the Lake El'gygytgyn diatom record suitable for (further) downcore $\delta^{18} \mathrm{O}$ analyses.

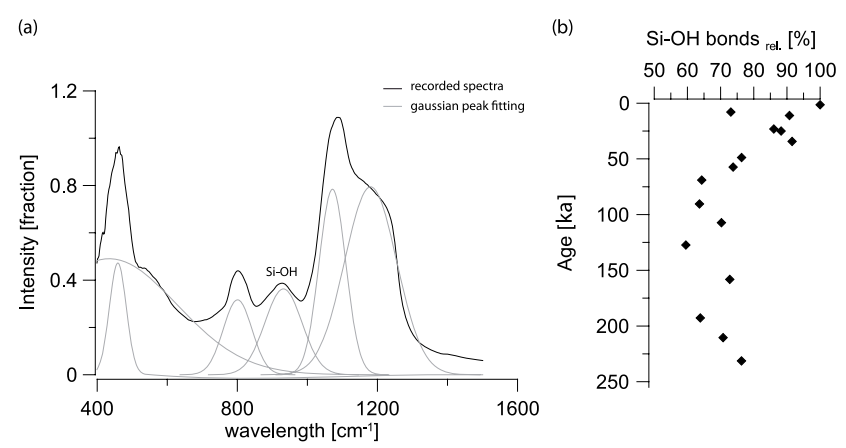

Fig. 4. Assessment of potential diagenetical changes. (a) gaussian peak fitting and peak centres for all silica modes, the $\mathrm{Si}-\mathrm{OH}$ bond peak is located at about $945 \mathrm{~cm}^{-1}$. (b) FTIRS analysis of 16 samples downcore.

\subsubsection{Lake temperature, blooming period and $\delta^{18} \mathrm{O}_{\text {water }}$}

Various environmental factors can influence the $\delta^{18} \mathrm{O}$-values of lacustrine, biogenic silica (Fig. 5). The lake temperature in which the diatoms grow has an effect on the fractionation between $\delta^{18} \mathrm{O}_{\text {water }}$ and $\delta^{18} \mathrm{O}_{\text {diatom }}$ of about $-0.2 \%{ }^{\circ} \mathrm{C}^{-1}$ 


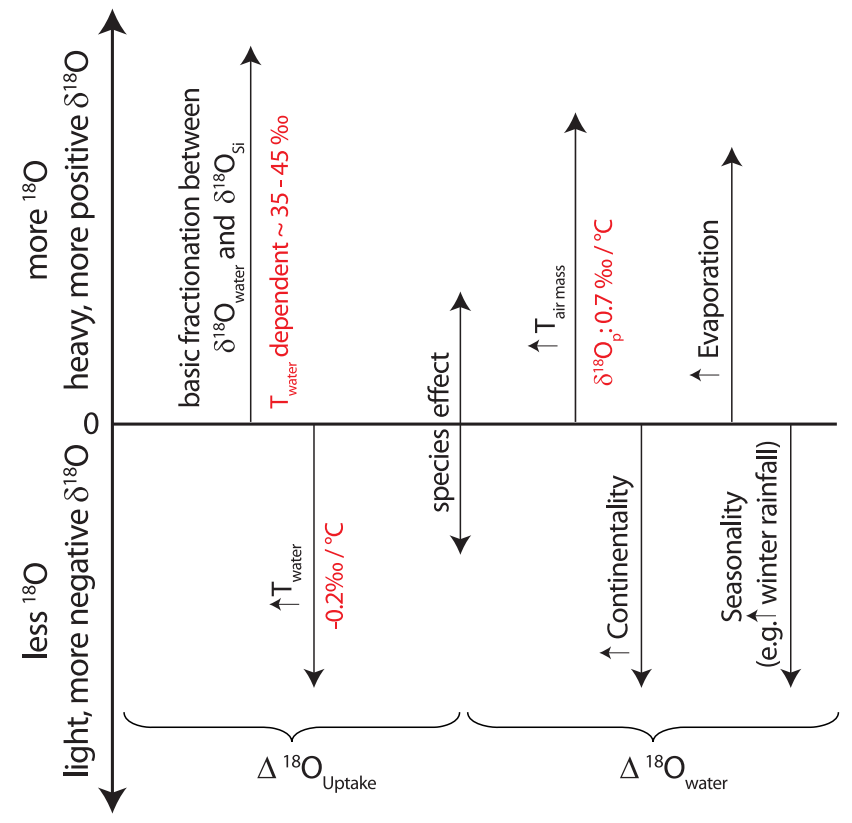

Fig. 5. $\delta^{18} \mathrm{O}_{\text {diatom }}$ controls in the lacustrine environment. $\Delta^{18} \mathrm{O}_{\text {uptake }}$ arrows mark direct fractionation mechanisms between $\delta^{18} \mathrm{O}_{\text {diatom }}$ and $\delta^{18} \mathrm{O}_{\text {lake water while }} \Delta^{18} \mathrm{O}_{\text {water }}$ arrows indicate atmospheric or hydrological processes influencing the $\delta^{18} \mathrm{O}_{\text {lake water }}$ and thus, indirect mechanisms on $\delta^{18} \mathrm{O}_{\text {diatom. Small up pointing }}$ arrows indicate an increase of the respective parameter.

(Brandriss et al., 1998; Moschen et al., 2005; Dodd and Sharp, 2010; Dong and JingTai, 2010). Lake El'gygytgyn lacks a true thermocline as in winter the lake is thermally stratified, but only with a difference of $2.3^{\circ} \mathrm{C}$ from the top to bottom of the water column $\left(0.7^{\circ} \mathrm{C}\right.$ at $3 \mathrm{~m}$ water depth, $3^{\circ} \mathrm{C}$ at $170 \mathrm{~m}$ depth). As soon as the ice melt begins, the first $30 \mathrm{~m}$ are mixed (at $1.4^{\circ} \mathrm{C}$, beginning of June) and in mid-July the lake is completely mixed with temperatures from July to mid-October ranging between $2.2^{\circ} \mathrm{C}$ to $3.8^{\circ} \mathrm{C}$ (observations from 2002, Nolan and Brigham-Grette, 2007). Diatoms are phototrophic organisms and the major blooming period was assessed by Cremer et al. (2005) from early spring (underice) through open-water conditions until the re-establishment of ice coverage in autumn, with the highest increase of $C y$ clotella ocellata in the first meters of the photic zone between 1 June and 20 July. Thus, due to this short major blooming period variations in lake temperature should not exceed $\pm 1{ }^{\circ} \mathrm{C}$, equal to water temperature-induced changes in $\delta^{18} \mathrm{O}$ values of $\pm 0.2 \%$, which is within the instruments error for biogenic silica $(1 \sigma=0.25 \%$, Chapligin et al., 2010). Chapligin et al. (2012) has further shown that no significant isotopic differences exist in the water column throughout various times of the year, so only minor effects from seasonality are expected to be reflected in $\delta^{18} \mathrm{O}_{\text {diatom }}$ values. With a deep photic zone of about $34 \mathrm{~m}$ (Dehnert and Juschus, 2008), good mixing conditions and a location in the cold Arctic environment, no significant impact on the $\delta^{18} \mathrm{O}_{\text {diatom-values from }}$ varying lake water temperature can be expected from different ages, samples or from taxa blooming in different seasons.

\subsubsection{Lake hydrology, ice-cover and $\delta^{18} \mathrm{O}_{\mathrm{p}}$}

Evaporation trends were not detected when analysing the $\delta^{18} \mathrm{O}$ lake water profile at three different times of the year (May, August, November; Chapligin et al., 2012). Despite the fact that these observations account mainly for the recent system, the reconstructed differences in lake level (terraces: $+35-40 \mathrm{~m}$, middle Pleistocene; $+9-11 \mathrm{~m}$, late Pleistocene; +2-3 m, Holocene; Glushkova and Smirnov, 2007) and subsequent differences in evaporation rates can potentially change the hydrological conditions (i.e. the residence time) and cause a shift in $\delta^{18} \mathrm{O}_{\text {lake water. }}$. However, changes in the extension of the photic zone should be considerably low throughout time. Hence, $\delta^{18} \mathrm{O}_{\text {diatom }}$ is basically influenced by $\delta^{18} \mathrm{O}_{\text {lake water. }}$.

In a deep, well-mixed lake such as Lake El'gygytgyn with little evaporation and a defined small catchment area, $\delta^{18} \mathrm{O}_{\text {lake water is mainly determined by the oxygen isotope }}$ composition of precipitation $\left(\delta^{18} \mathrm{O}_{\mathrm{p}}\right)$. Precipitation is either directly going into the lake or supplied via one of the small streams (Chapligin et al., 2012; Wilkie et al., 2012).

The residence time is about $100 \mathrm{yr}$ (Fedorov et al., 2012). For the last $100 \mathrm{yr}$, the isotope mass balance model of the lake (Wilkie et al., 2012) shows that this residence time buffers short-term changes and reduces the amplitude in $\delta^{18} \mathrm{O}_{\text {lake water }}$ (Wilkie et al., 2012). However, the low sedimentation rate only allowed for sampling on a centennial scale and for gaining average $\delta^{18} \mathrm{O}_{\text {diatom }}$ values. Compared to this sample-related time resolution and the relatively low resolution from the $\delta^{18} \mathrm{O}_{\text {diatom }}$ record (74 samples $/ 250 \mathrm{ka}$ ), the residence time can have reduced the amplitude by "cutting off local maxima or minima" of the $\delta^{18} \mathrm{O}_{\text {diatom }}$ record to a certain extent but considerably less than in the $100 \mathrm{yr}$ model.

Modern lake water isotope composition of $\delta^{18} \mathrm{O}_{\mathrm{AVG}}=$ $-19.8 \%$ (Chapligin et al., 2012) matches the oxygen isotope composition of precipitation ranging between -14 and $-34 \%$ for snow samples of single winter events (mean $-23.2 \%$ ) and rain $\delta^{18} \mathrm{O}$-values ranging from $-15.9 \%$ to $-12.4 \%$ (mean $-14.3 \%$ ) (Wilkie et al., 2012). Assuming a winter to summer precipitation ratio of $60 \%$ to $40 \%$ (Nolan and Brigham-Grette, 2007), the annual average of $\delta^{18} \mathrm{O}$-values would be $-19.3 \%$ o. Stream $\delta^{18} \mathrm{O}$-values ranged from $-24.2 \%$ to $-16.7 \%$ (Wilkie et al., 2012).

Hence, the oxygen isotope composition of the diatom samples reflects $\delta^{18} \mathrm{O}_{\text {lake water }}$, which is mainly controlled by $\delta^{18} \mathrm{O}_{\mathrm{p}}$ (pathway via streams or directly on/into the lake). This is in accordance with Swann et al. (2010). 


\subsubsection{Air temperature, air mass source and continentality}

The $\delta^{18} \mathrm{O}$ precipitation signal could be affected by varying air mass sources, air temperature, and/or continentality. According to Dansgaard (1964), the mean annual air temperature (MAAT) at surface is directly related to the mean annual $\delta^{18} \mathrm{O}_{\mathrm{p}}$ signal (shift of $+0.7 \% 0^{\circ} \mathrm{C}^{-1}$; in high latitudes/continental regions $+0.6 \% 0^{\circ} \mathrm{C}^{-1}$, Rozanski et al., 1993). Due to the relatively stable lake water temperatures and the negligible effect from $\Delta T_{\text {lake, }}$, we assume the effect of air temperature changes as predominant.

Nolan et al. (2012) identified modern synoptic weather patterns and climate trends affecting air temperatures from National Centers for Environmental Prediction (NCEP) global reanalysis data. Strong Aleutian lows and strong high pressure centres over the Arctic Ocean prevail in the winter, bringing cold Arctic air and moisture from the East and North to Lake El'gygytgyn. Summers are characterized by weak low pressure systems over Siberia and broad high pressure systems to the south and east providing warm continental air and recycled moisture to the lake.

For this area and the lake system, the general warming or cooling trends for air temperature are more important in contrast to changes in storm tracks being negligible (Nolan et al., 2012). Furthermore, Nolan et al. (2012) suggest that these weather patterns have been relatively stable with time and are likely representative of this and other interglacial periods. For Beringia, Mock et al. (1998) suggest the applicability of modern synoptic climatology to paleoclimate reconstruction.

The modern day and interglacial mean annual air temperature is $-10.3^{\circ} \mathrm{C}$ (Nolan and Brigham-Grette, 2007), while mean annual air temperatures for glacials were assumed to be about $-25^{\circ} \mathrm{C}$ using the coldest value from modern day NCEP daily reanalysis (Swann et al., 2010). Using the Dansgaard relationship of $+0.6 \% 0^{\circ} \mathrm{C}^{-1}$, this temperature difference of about $15^{\circ} \mathrm{C}$ is equivalent to a long-term amplitude in $\delta^{18} \mathrm{O}_{\mathrm{p}}$ by $9 \%$. This should be significantly higher when using MIS 5e (i.e. MIS 5.5) interglacial temperatures instead of modern day temperatures (Melles et al., 2012).

If only condensation temperature controlled this peak-topeak amplitude of $\Delta^{18} \mathrm{O}=5.3 \%$, this would correspond to a mean annual air temperature change of about $9^{\circ} \mathrm{C}$ between LGM and MIS 5.5 interglacial (Dansgaard, 1964). This temperature difference is in line with pollen-based reconstructions by Melles et al. (2012) who found a difference in mean temperatures of the warmest month between LGM and MIS 5.5 of around $9^{\circ} \mathrm{C}$.

Potentially, the change in the isotope signal due to air temperatures could be amplified by changes in continentality patterns. Lower sea levels and extended sea-ice in glacial periods increase the continentality of the location and the effect of the Rayleigh distillation, and thus, further decrease the $\delta^{18} \mathrm{O}_{\mathrm{p}}$. In contrast, there are three possibilities to explain a reduced amplitude. (1) The different lake temperature (about
$-0.2 \% 0^{\circ} \mathrm{C}^{-1}$ ) and air temperature (about $+0.6 \%{ }^{\circ} \mathrm{C}^{-1}$ ) factors cannot be mixed up and merged, as air temperature varies between glacial and interglacials from $-10.3{ }^{\circ} \mathrm{C}$ to $-25^{\circ} \mathrm{C}$ while water temperatures at these latitudes in well mixed lakes with a depth of $170 \mathrm{~m}$ must have been always around $4{ }^{\circ} \mathrm{C}$ with only small variations (modern and interglacial lake temperatures about $2-4{ }^{\circ} \mathrm{C}$; see Sect. 4.1.1). Hence, the effect from lake temperatures (e.g. potentially higher lake temperatures during the MIS 5.5 interglacial or the Greenland interstadial (1) would reduce the $\delta^{18} \mathrm{O}_{\text {diatom }^{-}}$ values, and thus, the amplitude slightly (e.g. by $1 \%$ when assuming a maximum temperature difference of 4 to $5^{\circ} \mathrm{C}$ ).

(2) The amplitude reduction from $\delta^{18} \mathrm{O}_{\mathrm{p}}$ to $\delta^{18} \mathrm{O}_{\text {water }}$ could also originate from the lake residence time, acting as a buffer for extreme variations in $\delta^{18} \mathrm{O}_{\mathrm{p}}$ over time (see Sect. 4.1.2). This effect could increase with longer residence time in cold phases generally characterized by lower temperature and humidity and thus potentially less moisture reaching the lake setting. (3) The global isotope-temperature relationship (Dansgaard, 1964) is based on recent precipitation from different regions. There is no detailed information if this $\delta^{18} \mathrm{O}_{\mathrm{p}^{-}}$ MAAT relationship is valid for the region, nor if it might have changed through time. Additionally, every single $\delta^{18} \mathrm{O}_{\text {diatom }}$ sample refers to centennial time scales, thus longer than the period considered by Dansgaard (1964). However, the reasonable order of magnitude of $\Delta^{18} \mathrm{O}$ in the Lake El'gygytgyn isotope record indicates that air temperatures should be the main driver.

\subsection{Comparison with other Lake El'gygytgyn records}

\subsection{1 $\quad \delta^{18} \mathrm{O}_{\text {diatom }}$ Holocene study}

Swann et al. (2010) examined the oxygen isotope composition of diatoms for the first $23 \mathrm{ka}$ at Lake El'gygytgyn in relatively high resolution (now until $2 \mathrm{kaBP}$ : every $0.17 \mathrm{ka}$; 2 k-22 ka BP: on average every 0.3 ka.; core Lz1029; Fig. 6). Differences exist between the two studies and a relatively constant offset of $3.4 \pm 1.0 \%, n=16$ was observed. The studies are compared and simplified in the following section to study1 (Swann et al., 2010) and study2 (our data). While for study 1 the 5-75 $\mu \mathrm{m}$ fraction was used (comprised of Cyclotella ocellata and Pliocaenicus costatus) to provide enough material for isotope analysis, in study 2 the $<10 \mu \mathrm{m}$ fraction was used in order to obtain single-species samples of Cyclotella ocellata. Differences in diatom assemblages (and different living conditions between both species) between the two studies could have caused the different $\delta^{18} \mathrm{O}$-values, although numerous studies have found no evidence of a species-dependent isotope fractionation in diatoms (Schmidt et al., 1997, 2001; Brandriss et al., 1998; Moschen et al., 2005). Chapligin et al. (2012) analysed the Pliocaenicus-dominated $>10 \mu \mathrm{m}$ fraction vs. the Cyclotelladominated $<10 \mu \mathrm{m}$ fraction for sub-surface samples from Lake El'gygytgyn and detected no significant difference in 


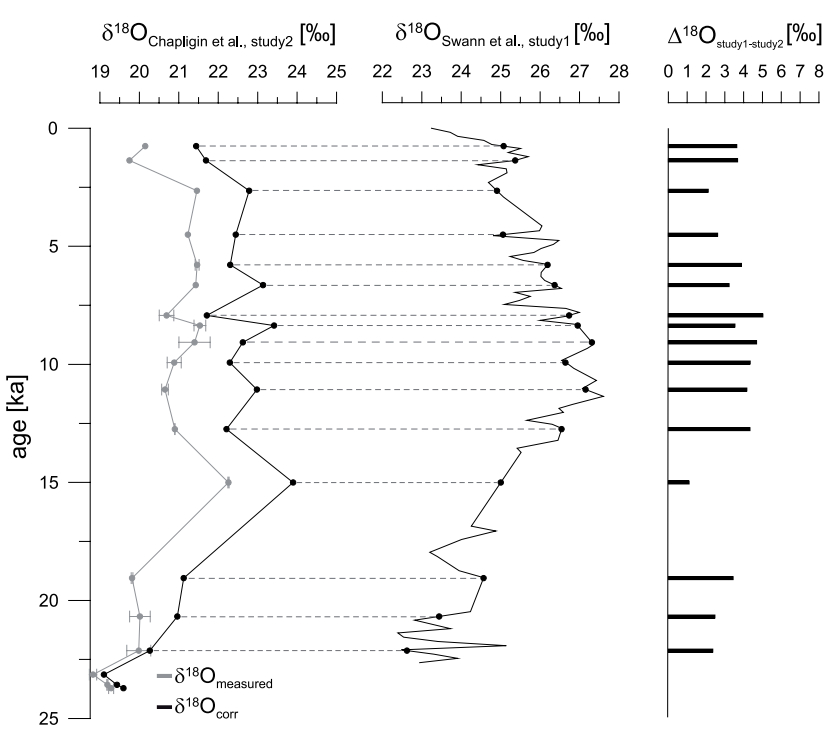

Fig. 6. Both existing studies on $\delta^{18} \mathrm{O}_{\text {diatom-values from Lake }}$ El'gygytgyn until the LGM. Left: our study (study2), uncorrected (grey) and corrected (black) $\delta^{18} \mathrm{O}$ record; middle: study by Swann et al. (2010) (study2); right: the resulting offsets between the two studies.

$\delta^{18} \mathrm{O}_{\text {diatom-values between the two size fractions after con- }}$ tamination correction.

The purity of diatoms in a sample could cause differences in $\delta^{18} \mathrm{O}$-values between both studies. The $\%$ cont. in study 1 was assessed by counting under a light microscope, resulting in a mean sample purity of $95.9 \pm 1.9 \%(1 \sigma)$, while study 2 showed a purity of $94.6 \pm 3.4 \%$. Study1 did not correct the measured values for contamination whereas study 2 did. However, higher contamination should cause lower $\delta^{18} \mathrm{O}$ values for study1, which is not the case.

Different dehydration techniques were applied in both laboratories (SWF, iGFD), but an inter-laboratory comparison showed for both techniques results within standard deviation on various biogenic working standards (Chapligin et al., 2011) between the two laboratories. The removal of Si$\mathrm{OH}$ groups in Nickel cylinders by using SWF as applied in study 1 could potentially remove oxygen from clay structures, whereas iGFD removes just $\mathrm{H}_{2} \mathrm{O}$ and - $\mathrm{OH}$ groups. However, study 2 corrected for contamination, so a significant difference due to different dehydration techniques can also be excluded. Both studies show different analytical reproducibility (mean SD $(1 \sigma)=0.34 \%$ for study 1 vs. $0.13 \%$ o for study2) but a similar trend can be observed. In both records, $\delta^{18} \mathrm{O}$-values increase until $8-10 \mathrm{ka}$, corresponding to the HTM (study1: +27.0 to $+27.4 \%$, increase between 3$10.7 \mathrm{ka}$; study2: $+23.4 \%$ o peak at $8.4 \mathrm{ka}$ ), and decrease until 20-22 ka, corresponding to the LGM (study1: +22.4 to $+22.5 \%$ at $21.4-21.6 \mathrm{ka}$; study $2:+19.1$ to $+20.3 \%$ at $22.1-$ $23.1 \mathrm{ka})$. Hence, no obvious reason for the offset in $\delta^{18} \mathrm{O}$ values between the two studies could be observed, but both records show similar trends, indicating that conclusions on palaeoclimatic changes can be drawn based on relative $\delta^{18} \mathrm{O}$ changes in the individual studies.

\subsubsection{Biogenic silica, $\mathrm{TiO}_{2}$, magnetic susceptibility}

For a longer time-series, we compared measurements of biogenic silica (BSi [\%]), $\mathrm{TiO}_{2}[\%]$ and magnetic susceptibility analysed on the same core (Lz1024; Frank et al., 2012) to our $\delta^{18} \mathrm{O}$ record (Fig. 7). BSi can be generally used as a proxy for nutrient availability and bioproductivity or primary production (Ragueneau et al., 2000). $\mathrm{TiO}_{2}$ is commonly used as a proxy for clastic sediment supply from fluvial (Haug et al., 2001) or eolian (Yancheva et al., 2007) transport and often related to weathering (Minyuk et al., 2011). To compare the $\delta^{18} \mathrm{O}$ record with both data sets (BSi record, Rosén et al., 2010; $\mathrm{TiO}_{2}$, Frank et al., 2012), we interpolated between sample depths to get comparable data. Both $\mathrm{BSi}$ and $\mathrm{TiO}_{2}$ records do not correlate well with the $\delta^{18} \mathrm{O}$ record $\left(\delta^{18} \mathrm{O}\right.$ vs. $\mathrm{BSi}, r=-0.14 ; \delta^{18} \mathrm{O}$ vs. $\mathrm{TiO}_{2}, r=-0.33$ ). The anticorrelation of the overall record is mainly due to the first three meters of the core and the high peak of BSi at the time interval corresponding to the LGM (around $1.6 \mathrm{~m}$ depth). High BSi percentages are not necessarily linked to increased temperatures but also to a higher nutrient availability. High $\mathrm{TiO}_{2}$ percentages can be explained by enhanced weathering (maximum in $\mathrm{TiO}_{2}$ percentage). This is accompanied by a minimum in $\delta^{18} \mathrm{O}$-values in cold periods.

Magnetic susceptibility in lake sediments reflects the concentration of magnetic mineral phases, which is controlled by preservation in Lake El'gygytgyn sediments (Nowaczyk et al., 2007). Anoxic bottom and pore waters dissolve the respective mineral phases while keeping preserved under oxic conditions. Thus, high and low magnetic susceptibility values can represent interglacials and glacials but a high organic content during interglacials can also induce anoxic bottom water conditions.

None of the compared proxies are directly related to temperature and precipitation, and hence only weak correlations exist between these proxies and the diatom $\delta^{18} \mathrm{O}$ signal. It is remarkable, though, that $\delta^{18} \mathrm{O}$ peaks often occur earlier than $\mathrm{TiO}_{2}$ minima or BSi maxima percentages (cf. $\delta^{18} \mathrm{O}$ at $5.50-$ $6.22 \mathrm{~m}$ depth vs. $\mathrm{TiO}_{2}$ and $\mathrm{BSi}$ at $5.30-5.80 \mathrm{~m} ; \delta^{18} \mathrm{O}, 2.40-$ $2.70 \mathrm{~m}$ vs. $\mathrm{TiO}_{2}$ and $\mathrm{BSi}, 2.40-2.00 \mathrm{~m}$ ), which could indicate a more direct atmospheric signal responsible for $\delta^{18} \mathrm{O}$, while there is a delayed reaction in the more indirect proxy records due to subsequent weathering $\left(\mathrm{TiO}_{2}\right)$ and nutrient availability (BSi).

\subsection{Comparison with other regional and global climate records}

The diatom $\delta^{18} \mathrm{O}$ record was compared with prominent climate curves such as the global marine $\delta^{18} \mathrm{O}$ benthic stack LR04 (Lisiecki and Raymo, 2005; henceforth simplified to 


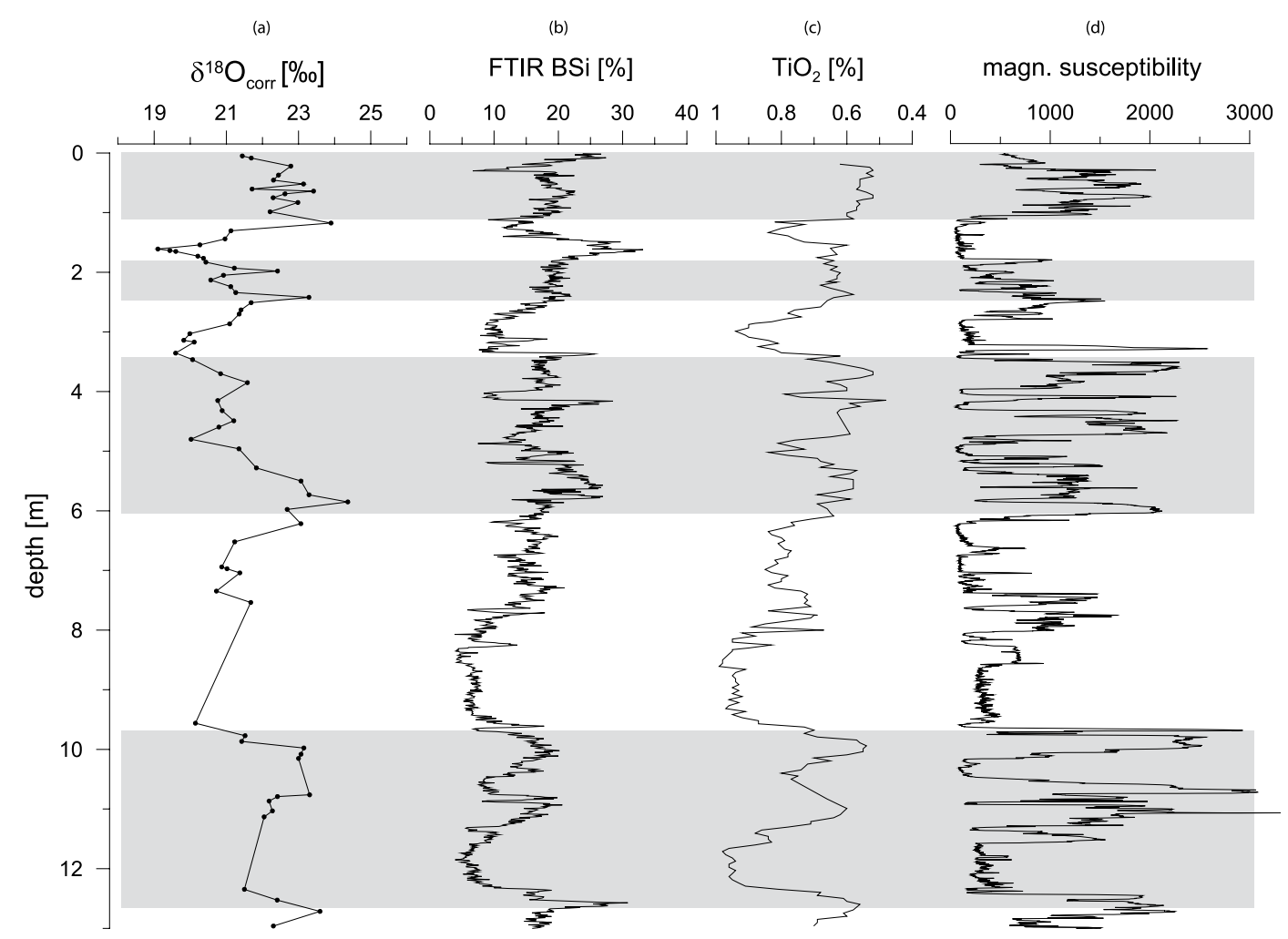

Fig. 7. Comparison of the (a) $\delta^{18} \mathrm{O}_{\text {diatom }}$ record with other Lake El'gygytgyn records: (b) $\mathrm{TiO}_{2}$ [\%], (c) BSi [\%] (both Frank et al., 2012) analysed with FTIRS (Rosén et al., 2010) and (d) magnetic susceptibility for core Lz1024. Shaded parts indicate interglacial periods.

LR04) and the glacial $\delta^{18} \mathrm{O}$ record from the North Greenland Ice Core Project (NGRIP; North-Greenland-Ice-CoreProject members, 2004; henceforth simplified to NGRIP). As this latter record ends at $\sim 123 \mathrm{ka}$, the $\delta \mathrm{D}$ Dome-C record from the European Project for Ice Coring in Antarctica (EPICA; EPICA members, 2004 and 2006; henceforth simplified to EPICA) was used for comparison further downcore as well as the mean monthly (July) insolation at $67^{\circ} \mathrm{N}$ (Laskar et al., 2004), being indicative for the main diatom blooming period (Fig. 8).

For comparing the EPICA, the LR04 record and the mean monthly (July) insolation at $67^{\circ} \mathrm{N}$ with our $\delta^{18} \mathrm{O}$ record we interpolated between sample ages. The correlation of the diatom $\delta^{18} \mathrm{O}$ record and the stacked $\delta^{18} \mathrm{O}$ LR04 record (Fig. 9; $r=+0.58$ ) and $\delta$ D EPICA record (Fig. 9; $r=+0.69)$ are significant $(p<0.05)$, indicating that a clear precipitation driven climate signal is preserved in the $\delta^{18} \mathrm{O}$ record from diatoms at Lake El'gygytgyn.

The correlation between the diatom $\delta^{18} \mathrm{O}$ record and the mean monthly (July) insolation at $67^{\circ} \mathrm{N}$ is $r=+0.56$. When correlating this record to the different Milankovitch cycles, the $41 \mathrm{ka}$ cycle caused by the obliquity of the ecliptic is clearly the best fit $(r=+0.67$; eccentricity: $r=+0.29$; precession: $r=-0.30)$. Hence, solar forcing, especially the 41 ka obliquity cycle, seems to be the main forcing factor on longer time scales for $\delta^{18} \mathrm{O}$ in diatoms at Lake El'gygytgyn.
On the one hand, this further supports the proposed age model, on the other hand this shows the potential of $\delta^{18} \mathrm{O}$ in diatoms at Lake El'gygytgyn as a long-term climate archive back to 3.6 Ma.

\subsection{Paleoclimate reconstruction}

Glacial-interglacial cycles are clearly visible in the presented $\delta^{18} \mathrm{O}_{\text {diatom }}$ record at Lake El'gygytgyn dating back to $250 \mathrm{ka}$. This includes prominent minima and maxima such as the Holocene Thermal Maximum (HTM, $\delta^{18} \mathrm{O}$ around $+23 \%$, $8.9 \mathrm{ka})$. A post-HTM cooling trend can be observed, while in the pre-HTM time the Younger Dryas stadial (Greenland Stadial 1) has not been identified in the $\delta^{18} \mathrm{O}$ record, which might be due to the relatively low resolution. However, in the higher resolved $\delta^{18} \mathrm{O}$ record of Swann et al. (2010) a local minimum in the Younger Dryas exists, but is not clearly visible within the general trend. The $\operatorname{LGM}\left(\delta^{18} \mathrm{O}=+19.1 \%\right.$, $23.1 \mathrm{ka})$ reflects the absolute minimum of the record and corresponds to minima in the $\delta^{18} \mathrm{O}$ NGRIP, $\delta$ D EPICA Dome-C and stacked $\delta^{18} \mathrm{O}$ LR04 records (Fig. 8) as well as in the July insolation record from $67^{\circ} \mathrm{N}$. However, the LGM minimum in the Lake El'gygytgyn $\delta^{18} \mathrm{O}$ record is earlier than those in LR04 and EPICA (20-18 ka), whereas the insolation minimum at $67^{\circ} \mathrm{N}$ occurs at the same time $(\sim 23 \mathrm{ka})$. Despite the relatively low resolution, two maxima in the MIS 3 


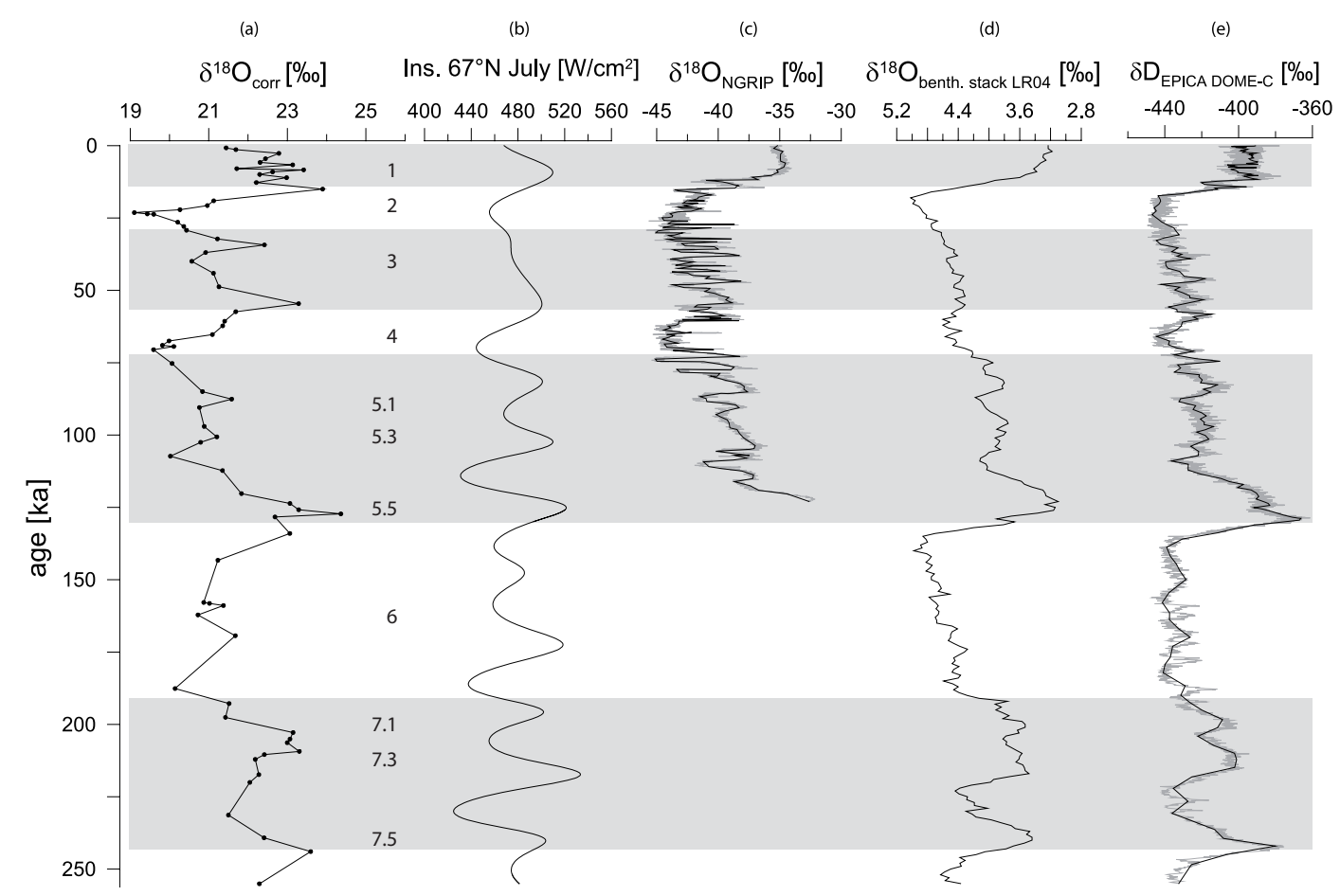

Fig. 8. (a) The $\delta^{18} \mathrm{O}_{\text {diatom }}$ record is plotted versus (b) July insolation at $67^{\circ} \mathrm{N}$ (Laskar et al., 2004) (c) $\delta^{18} \mathrm{O}$ from the ice-core record NGRIP (North-Greenland-Ice-Core-Project members, 2004) (d) the stacked marine oxygen isotope record LR04 (Lisiecki and Raymo, 2005) and (e) $\delta \mathrm{D}$ from EPICA Dome-C ice-core record (EPICA members, 2004, 2006). For both ice-core records: complete record in grey; spline smoothing in black. Warmer periods corresponding to MIS 1, MIS 3, MIS 5 and MIS 7 are marked in grey, interglacials and significant interstadials are labelled.

interstadial can be distinguished. These maxima generally coincide with the mid MIS 3 warm phase $(+22.4 \%$ o, $34.3 \mathrm{ka})$ and early MIS 3 warm phase $(+23.3 \%$ o, $54.6 \mathrm{ka})$, as stated for Siberia (e.g. Swann et al., 2005). The colder MIS 4 is reflected by relatively lower $\delta^{18} \mathrm{O}$-values between 70 and $60 \mathrm{ka}$. The local minimum $\left(\delta^{18} \mathrm{O}=+19.6 \%\right)$, verified by multiple data points, occurs at $\sim 70 \mathrm{ka}$ and matches the NGRIP and the insolation minimum. After the LGM minimum it is the second lowest minimum, reflecting a cold time period. The MIS 4 is preceded by a characteristic maximum corresponding to the MIS 5.5 interglacial $(+24.4 \%$ o, $127.2 \mathrm{ka})$ being the absolute maximum of the record. Again, this maximum correlates well with the maxima of the EPICA and the insolation record. However, the increase towards higher $\delta^{18} \mathrm{O}$ values occurs earlier than in the other records and already at $\sim 133 \mathrm{ka}$ the values are close to the peak maximum. Further maxima are present in the time interval corresponding to MIS 7.1 and 7.3 (plateau $\sim+23.0 \%, \sim 209-203 \mathrm{ka}$ ) as well as MIS $7.5(+23.6 \%$, $244.0 \mathrm{ka})$. The intermediate period of MIS 7.2 could not be detected despite the analysis of four samples within this time. Hence, the $\delta^{18} \mathrm{O}$ record shows a plateau which is more similar to the weakly developed minima of the EPICA and LR04 records than to the distinct minimum of the insolation record at $\sim 206 \mathrm{ka}$. The $\delta^{18} \mathrm{O}$ minimum corresponding to MIS $7.4(+21.5 \%$, $\sim 231 \mathrm{ka}$ ) correlates well with the EPICA, LR04 and insolation minima. The time corresponding to MIS 7.5 is reflected by the local $\delta^{18} \mathrm{O}$ maximum $(+23.6 \%$ o, $244.0 \mathrm{ka})$, which occurs slightly earlier than in the EPICA, LR04 and insolation record $(\sim 240 \mathrm{ka})$.

According to the presented $\delta^{18} \mathrm{O}_{\text {diatom }}$ record of Lake El'gygytgyn, similar temperatures occurred in the time of the HTM, MIS 3 and MIS 7, whereas the MIS 5.5 interglacial was warmer than the Holocene. Comparing similar peak average $\delta^{18} \mathrm{O}$-values from HTM $(+22.8 \% ; 11.1-8.4 \mathrm{ka})$ and MIS 7 (+22.6\%o; 244.0-202.8 ka) with $\delta^{18} \mathrm{O}$-values from the time corresponding to MIS $5.5(+23.6 \%$; $127.2-123.6 \mathrm{ka})$, the values differ by $0.8-1.0 \%$, equivalent to about 1 to $1.5^{\circ} \mathrm{C}$ difference in mean annual air temperature (MAAT) (Dansgaard, 1964; Rozanski et al., 1993; calculated as described in Sect. 4.1.4). This is in the range of the pollen spectra temperature reconstructions by Melles et al. (2012) who found the MIS 5.5 to have slightly higher mean temperatures of the warmest month (MTWM, i.e. July) as compared to the HTM data. The most recent $\delta^{18} \mathrm{O}$-value of $+21.4 \%$ is around $1.5 \%$ oblow the HTM $\delta^{18} \mathrm{O}$-value and corresponds to a MAAT decrease of about $2^{\circ}$ to $2.5^{\circ} \mathrm{C}$, which slightly exceeds pollen-based reconstructions by Melles et al. (2012) (MWTM difference $\sim 1^{\circ}$ to $2^{\circ} \mathrm{C}$ between today and both HTM and MIS 5e=MIS 5.5). In the global marine LR04 

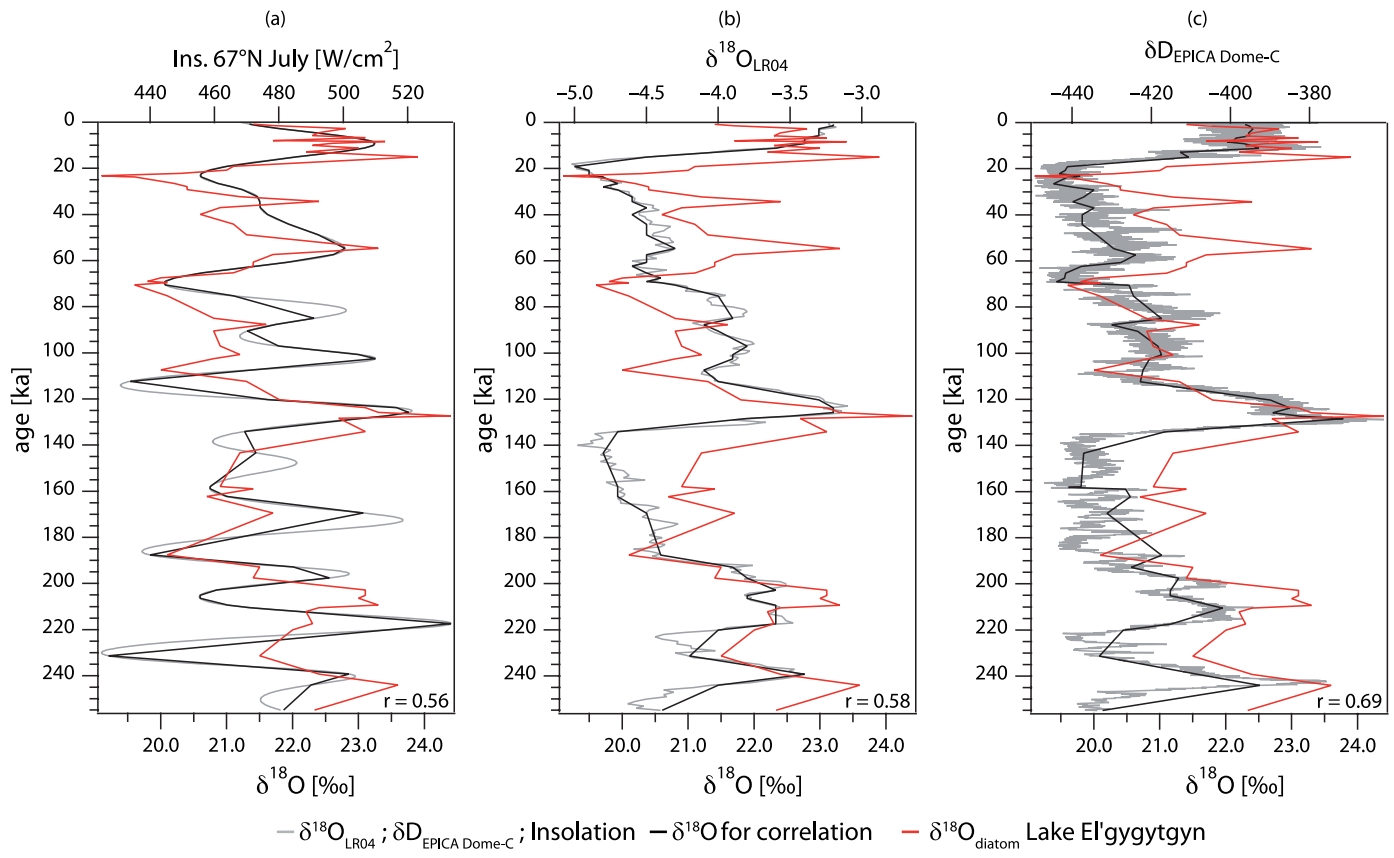

Fig. 9. Correlation between the $\delta^{18} \mathrm{O}_{\text {diatom }}$ record and (a) mean monthly insolation (July) (b) the marine LR04 stack and (c) the $\delta D_{\text {EPICA Dome-C }}$ record.

record, abrupt warming and slow cooling trends were observed, whereas in our $\delta^{18} \mathrm{O}$ record both warming and cooling processes seem to occur with the same speed. However, the reason for the different reaction time is not yet understood but may be linked to the fast reaction time of the lake water to climate change.

\section{Conclusions}

Samples from the upper $13 \mathrm{~m}$ (dating back about $250 \mathrm{ka}$ ) of the $16.5 \mathrm{~m}$ sediment core drilled at Lake El'gygytgyn (far east Russian Arctic) were analysed for the oxygen isotope composition of biogenic silica (diatoms). For this purpose the $<10 \mu \mathrm{m}$ fraction was used, showing mostly a monospecific diatom assemblage of Cyclotella ocellata. Sample purity was analysed by EDS and $\delta^{18} \mathrm{O}_{\text {diatom-values cor- }}$ rected using geochemical mass-balancing. Despite a decreasing trend in silanol group percentages of about $25 \%$ from the topmost sample downcore detected by FTIRS, this diagenetic change is not reflected in the $\delta^{18} \mathrm{O}$ record. The $\delta^{18} \mathrm{O}_{\text {diatom }}$ signal is clearly controlled by the $\delta^{18} \mathrm{O}$ signal from precipitation (driven by temperature at the point of condensation in the atmosphere) with downcore variations, indicating that glacial-interglacial cycles are present throughout the whole core. The Holocene Thermal Maximum (HTM; $\delta^{18} \mathrm{O}$ peak around $+23 \%$; $8.9 \mathrm{ka}$ ), the Last Glacial Maximum (LGM; $+19.1 \% o, 23.1 \mathrm{ka}$ ) as well as the MIS 5.5 interglacial $(+24.4 \%$ o, $127.2 \mathrm{ka})$ and the interval corresponding to MIS 7.1, 7.3 (plateau around $+23.0 \%$, 209-203 ka) and MIS
$7.5(+23.6 \%$ o, 244.0 ka) are clearly visible. A peak-to-peak amplitude of $\Delta^{18} \mathrm{O}=5.3 \%$ o between the MIS 5.5 absolute maximum and the LGM absolute minimum was detected. This shift would be equal to a change in mean annual air temperature of about $9^{\circ} \mathrm{C}$ when assuming that changes in

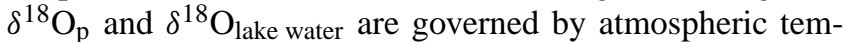
perature at the point of condensation $\left(+0.6 \%{ }^{\circ} \mathrm{C}^{-1}\right.$ for high latitudes). However, variations in moisture source and continentality could be still masked within this difference.

Generally, the $\delta^{18} \mathrm{O}$ record tends to peak earlier than the weathering $\left(\mathrm{TiO}_{2}[\%]\right)$ or bioproductivity (BSi [\%]) proxy records, indicating that $\delta^{18} \mathrm{O}$ precipitation signal rapidly responds to global/regional climate change while $\mathrm{TiO}_{2}$ reacts on enhanced weathering in cold periods or BSi percentages increase after warmer time intervals with a certain delay. The correlations of the $\delta^{18} \mathrm{O}$ record with the $\delta^{18} \mathrm{O}$ benthic stack LR04 $(r=0.58)$ and the $\delta$ D EPICA Dome$\mathrm{C}$ record $(r=0.69)$ are significant and show the sensitivity of Lake El'gygytgyn and the wider Arctic climate system to global climate conditions. However, when comparing Lake El'gygytgyn to these global records, the LGM, MIS 7.5 and the $\delta^{18} \mathrm{O}$-values increase towards the MIS 5.5 occur earlier. From the Milankovitch cycles the $41 \mathrm{ka}$ obliquity cycle correlates best with the $\delta^{18} \mathrm{O}$ record and is most likely one of the main forcing factors on longer time scales for $\delta^{18} \mathrm{O}$ in diatoms at Lake El'gygytgyn. This is the longest continuous terrestrial $\delta^{18} \mathrm{O}$ record from the Arctic directly reflecting $\delta^{18} \mathrm{O}$ precipitation signals. The work will be expanded to sediment core 5011-1 (dating back to about 3.6 Ma), which 
was drilled within the ICDP program at Lake El'gygytgyn in early 2009.

Acknowledgements. The authors would like to thank the German Research Foundation which funded the work with the research grants DFG Me 3266-1-1 and 3266-1-2. Martin Melles, Olaf Juschus, Volker Wennrich from the University of Cologne and the complete group of the Expedition 2003 is thanked for coring and sample taking, and Olaf Juschus for drying and packaging the samples. Thoralf Arendt's and Allison Bryan's work in supporting the preparation and counting as well as the statistical support from Andreas Wirsing are greatly acknowledged. In addition, our sincere gratitude goes to Peter Rosén from the Climate Impacts Research Centre (CIRC), Abisko/Umeå Universitet and Per Persson, Umeå University for FTIRS measurements. We are deeply thankful for the willingness of Pavel Minyuk $\left(\mathrm{TiO}_{2}\right)$, Norbert Nowaczyk (magnetic susceptibility) and Hendrik Vogel (BSi) to share their data sets for using them for comparison. The authors thank Lutz Schirrmeister and Georg Schwamborn, Anson Mackay and one anonymous reviewer for their constructive comments which helped to improve the quality of the manuscript.

Edited by: B. Wagner

\section{References}

Anisimov, O. A., Vaughan, D. G., Callaghan, T. V., Furgal, C., Marchant, H., Prowse, T. D., Vilhjálmsson, H., and Walsh, J. E.: Polar regions (Arctic and Antarctic), Climate Change 2007: Impacts, Adaptation and Vulnerability, in: Contribution of Working Group II to the Fourth Assessment Report of the Intergovernmental Panel on Climate Change, edited by: Parry, M. L., Canziani, O. F., Palutikof, J. P., van der Linden, P. J., and Hanson, C. E., Cambridge University Press, Cambridge, 2007.

Bekryaev, R. V., Polyakov, I. V., and Alexeev, V. A.: Role of Polar Amplification in Long-Term Surface Air Temperature Variations and Modern Arctic Warming, J. Climate, 23, 3888-3906, 2010.

Bezrukova, E., Krivonogov, S. K., Takahara, H., Letunova, P. P., Shichi, K., Abzaeva, A. A., Kulagina, N. V., and Zabelina, Y. S.: Lake Kotokel as a stratotype for the late glacial and Holocene in southeastern Siberia, Dokl. Earth Sci., 420, 658-663, 2008.

Brandriss, M. E., O’Neil, J. R., Edlund, M. B., and Stoermer, E. F.: Oxygen isotope fractionation between diatomaceous silica and water, Geochim. Cosmochim. Ac., 62, 1119-1125, 1998.

Brewer, T. S., Leng, M. J., Mackay, A. W., Lamb, A. L., Tyler, J. J., and Marsh, N. G.: Unravelling contamination signals in biogenic silica oxygen isotope composition; the role of major and trace element geochemistry, J. Quaternary Sci., 23, 321-330, 2008.

Brigham-Grette, J.: New perspectives on Beringian Quaternary paleogeography, stratigraphy, and glacial history, Quaternary Sci. Rev., 20, 15-24, 2001.

Brigham-Grette, J., Melles, M., Minyuk, P. S., and Scientific Party: Overview and significance of a 250 ka paleoclimate record from El'gygytgyn Crater Lake, NE Russia, J. Paleolimnol., 37, 1-16, 2007.
CCSP: Past Climate Variability and Change in the Arctic and at High Latitudes, A report by the US Climate Change Science Program and Subcommittee on Global Change Research, coordinating lead authors: Alley, R. B., Brigham-Grette, J., Miller, G. H., Polyak, L., and White, J. W. C., US Geological Survey, Reston, VA, 257 pp., 2009.

Chapligin, B., Meyer, H., Friedrichsen, H., Marent, A., Sohns, E., and Hubberten, H. W.: A high-performance, safer and semiautomated approach for the $\delta^{18} \mathrm{O}$ analysis of diatom silica and new methods for removing exchangeable oxygen, Rapid Commun. Mass Sp., 24, 2655-2664, 2010.

Chapligin, B., Leng, M. J., Webb, E., Alexandre, A., Dodd, J. P., Ijiri, A., Lücke, A., Shemesh, A., Abelmann, A., Herzschuh, U., Longstaffe, F. J., Meyer, H., Moschen, R., Okazaki, Y., Rees, N. H., Sharp, Z. D., Sloane, H. J., Sonzogni, C., Swann, G. E. A., Sylvestre, F., Tyler, J. J., and Yam, R.: Inter-laboratory comparison of oxygen isotope compositions from biogenic silica, Geochim. Cosmochim. Ac., 75, 7242-7256, 2011.

Chapligin, B., Meyer, H., Bryan, A., Snyder, J., and Kemnitz, H.: Assessment of purification and contamination correction methods for analysing the oxygen isotope composition from biogenic silica, Chem. Geol., 300-301, 185-199, 2012.

Cherapanova, M. V., Snyder, J. A., and Brigham-Grette, J.: Diatom stratigraphy of the last $250 \mathrm{ka}$ at Lake El'gygytgyn, northeast Siberia, J. Paleolimnol., 37, 155-162, 2007.

Cremer, H., Wagner, B., Juschus, O., and Melles, M.: A microscopical study of diatom phytoplankton in deep crater Lake El'gygytgyn, Northeast Siberia, Algol. Studies, 116, 147-169, 2005.

Dansgaard, W.: Stable isotopes in precipitation, Tellus, 16, 436468, 1964.

Dehnert, A. and Juschus, O.: Rezente Sedimentation im Elgygytgyn-See, NE Sibirien, abgeleitet aus der Zusammensetzung von Oberflächensedimenten, Leipziger Geowissenschaften, Leipzig, 35-51, 2008.

Dodd, J. P. and Sharp, Z. D.: A laser fluorination method for oxygen isotope analysis of biogenic silica and a new oxygen isotope calibration of modern diatoms in freshwater environments, Geochim. Cosmochim. Ac., 74, 1381-1390, 2010.

Dong, L. and JingTai, H.: Temperature-induced fractionation of oxygen isotopes of diatom frustules and growth water in Lake Sihailongwan in Northeast China, Chinese Sci. Bull., 55, 37943801, 2010.

Dyke, A. S. and Prest, V. K.: Late Wisconsinan history of the Laurentide ice sheet, Geographie Physique et Quaternaire XLI 237263, 1987.

EPICA members: Eight glacial cycles from an Arctic ice core, Nature, 429, 623-628, 2004.

EPICA members: One-to-one coupling of glacial climate variability in Greenland and Antarctica, Nature, 444, 195-198, doi:10.1038/nature05301, 2006.

Fedorov, G., Nolan, M., Brigham-Grette, J., Bolshiyanov, D., Schwamborn, G., and Juschus, O.: Lake El'gygytgyn water and sediment balance components overview and its implications for the sedimentary record, Clim. Past Discuss., 8, 3977-4001, doi:10.5194/cpd-8-3977-2012, 2012. 
Frank, U., Nowaczyk, N. R., Minyuk, P., Vogel, H., Rosen, P., and Melles, M.: A $350 \mathrm{ka}$ record of climate change from Lake El'gygytgyn, Far East Russian Arctic: Refining the pattern of climate modes by means of cluster analysis, Clim. Past Discuss., accepted, 2012.

Fröhlich, F.: Deep-sea biogenic silica: new structural and analytical data from infrared analysis - geological implications, Terra Nova, 1, 267-273, 1989.

Gendron-Badou, A., Coradin, T., Maquet, J., Fröhlich, F., and Livage, J.: Spectroscopic characterization of biogenic silica, J. Non-Cryst. Solids, 316, 331-337, 2003.

Glushkova, O. Y.: Geomorphological correlation of Late Pleistocene glacial complexes of Western and Eastern Beringia, Quaternary Sci. Rev., 20, 405-417, 2001.

Glushkova, O. Y. and Smirnov, V. N.: Pliocene to Holocene geomorphic evolution and paleogeography of the El'gygytgyn Lake region, NE Russia, J. Paleolimnol., 37, 37-47, 2007.

Greenland-Ice-Core-Project members: Climate instability during the last interglacial period recorded in the GRIP ice core, Nature, 364, 203-207, 1993.

Grootes, P. M., Stuiver, M., White, J. W. C., Johnsen, S., and Jouzel, J.: Comparison of oxygen isotope records from the GISP2 and GRIP Greenland ice cores, Nature, 366, 552-554, 1993.

Haug, G. H., Hughen, K. A., Sigman, D. M., Peterson, L. C., and Röhl, U.: Southward Migration of the Intertropical Convergence Zone Through the Holocene, Science, 293, 1304-1308, 2001.

Hopkins, D. M.: The Bering Land Bridge, Stanford University Press, Stanford, 1967.

Hopkins, D. M., Matthews Jr., J. V., Schweger, C. E., and Young, S. B.: Paleoecology of Beringia, Academic Press, New York, 489 pp., 1982.

Hubberten, H. W., Andreev, A., Astakhov, V. I., Demidov, I., Dowdeswell, J. A., Henriksen, M., Hjort, C., Houmark-Nielsen, M., Jakobsson, M., Kuzmina, S., Larsen, E., Lunkka, J. P., Lyså, A., Mangerud, J., Möller, P., Saarnisto, M., Schirrmeister, L., Sher, A. V., Siegert, C., Siegert, M. J., and Svendsen, J. I.: The periglacial climate and environment in northern Eurasia during the Last Glaciation, Quaternary Sci. Rev., 23, 1333-1357, 2004.

Juillet-Leclerc, A. and Labeyrie, L.: Temperature dependence of the oxygen isotopic fractionation between diatom silica and water, Earth Planet. Sc. Lett., 84, 69-74, 1987.

Juschus, O., Preusser, F., Melles, M., and Radtke, U.: Applying SAR-IRSL methodology for dating fine-grained sediments from Lake El'gygytgyn, north-eastern Siberia, Quat. Geochronol., 2, 187-194, 2007.

Kaufman, D. S., Schneider, D. P., McKay, N. P., Ammann, C. M., Bradley, R. S., Briffa, K. R., Miller, G. H., Otto-Bliesner, B. L., Overpeck, J. T., Vinther, B. M., and Arctic Lakes 2k Project Members: Recent Warming Reverses Long-Term Arctic Cooling, Science, 325, 1236-1239, 2009.

Kostrova, S. S., Meyer, H., Chapligin, B., Kossler, A., Bezrukova, E. V., and Tarasov, P. E.: Holocene oxygen isotope record of diatoms from Lake Kotokel (southern Siberia, Russia) and its palaeoclimatic implications, Quaternary Int., in press, 2012.

Kurita, N., Yoshida, N., Inoue, G., and Chayanova, E. A.: Modern isotope climatology of Russia: A first assessment, J. Geophys. Res., 109, D03102, doi:10.1029/2003JD003404, 2004.
Lamb, A. L., Brewer, T. S., Leng, M. J., Sloane, H. J., and Lamb, H. F.: A geochemical method for removing the effect of tephra on lake diatom oxygen isotope records, J. Paleolimnol., 37, 499516, 2007.

Laskar, J., Robutel, P., Joutel, F., Gastineau, M., Correia, A. C. M., and Levrard, B.: A long-term numerical solution for the insolation quantities of the Earth, Astron. Astrophys., 428, 261-285, 2004.

Layer, P. W.: Argon-40/argon-39 age of the El'gygytgyn impact event, Chukotka, Russia, Meteorit. Planet. Sci., 35, 591-599, 2000.

Lehman, S. J., Jones, G. A., Keigwin, L. D., Andersen, E. S., Butenkoi, G., and Ostmo, S. R.: Initiation of Fennoscandian icesheet retreat during the last deglaciation, Nature, 349, 513-516, 1991.

Leng, M. J. and Barker, P. A.: A review of the oxygen isotope composition of lacustrine diatom silica for palaeoclimate reconstruction, Earth-Sci. Rev., 75, 5-27, 2006.

Leng, M. J. and Marshall, J. D.: Palaeoclimate interpretation of stable isotope data from lake sediment archives, Quaternary Sci. Rev., 23, 811-831, 2004.

Leng, M. J. and Sloane, H. J.: Combined oxygen and silicon isotope analysis of biogenic silica, J. Quaternary Sci., 23, 313-319, 2008.

Leng, M., Barker, P., Greenwood, P., Roberts, N., and Reed, J.: Oxygen isotope analysis of diatom silica and authigenic calcite from Lake Pinarbasi, Turkey, J. Paleolimnol., 25, 343-349, 2001.

Leng, M., Swann, G. E. A., Hodson, M. J., Tyler, J. J., Patwardhan, S. W., and Sloane, H. J.: The Potential use of Silicon Isotope Composition of Biogenic Silica as a Proxy for Environmental Change, Silicon, 1, 65-77, 2009.

Lisiecki, L. E. and Raymo, M. E.: A Pliocene-Pleistocene stack of 57 globally distributed benthic $\delta^{18} \mathrm{O}$ records, Paleoceanography, 20, PA1003, doi:10.1029/2004PA001071, 2005.

Mackay, A. W., Swann, G. E. A., Brewer, T. S., Leng, M. J., Morley, D. W., Piotrowska, N., Rioual, P., and White, D.: A reassessment of late glacial - Holocene diatom oxygen isotope record from Lake Baikal using a geochemical mass-balance approach, J. Quaternary Sci., 26, 627-634, 2011.

Melles, M., Minyuk, P. S., Brigham-Grette, J., and Juschus, O.: The Expedition El'gygytgyn Lake 2003 (Siberian Arctic), Ber. Polarforsch. Meeresforsch., 509, 2005.

Melles, M., Brigham-Grette, J., Glushkova, O. Y., Minyuk, P. S., Nowaczyk, N. R., and Hubberten, H.: Sedimentary geochemistry of core PG1351 from Lake El'gygytgyn - a sensitive record of climate variability in the East Siberian Arctic during the past three glacial-interglacial cycles, J. Paleolimnol., 37, 89-104, 2007.

Melles, M., Brigham-Grette, J., Minyuk, P., Koeberl, C., Andreev, A., Cook, T., Fedorov, G., Gebhardt, C., Haltia-Hovi, E., Kukkonen, M., Nowaczyk, N., Schwamborn, G., Wennrich, V., and El'gygytgyn Scientific Party: The El'gygytgyn Scientific Drilling Project - conquering Arctic challenges through continental drilling, Scientific Drilling, 11, 29-40, 2011.

Melles, M., Brigham-Grette, J., Minyuk, P. S., Nowaczyk, N. R., Wennrich, V., DeConto, R. M., Anderson, P. M., Andreev, A. A., Coletti, A., Cook, T. L., Haltia-Hovi, E., Kukkonen, M., Lozhkin, A. V., Rosén, P., Tarasov, P., Vogel, H., and Wagner, B.: 2.8 Million Years of Arctic Climate Change from Lake El'gygytgyn, NE Russia, Science, 337, 315-320, doi:10.1126/science.1222135, 
2012.

Miller, G. H., Alley, R. B., Brigham-Grette, J., Fitzpatrick, J. J., Polyak, L., Serreze, M. C., and White, J. W. C.: Arctic amplification: can the past constrain the future?, Quaternary Sci. Rev., 29, 1779-1790, 2010.

Minyuk, P., Borkhodoev, V., and Goryachev, N.: Geochemical characteristics of sediments from Lake El'gygytgyn, Chukotka Peninsula, as indicators of climatic variations for the past $350 \mathrm{ka}$, Dokl. Earth Sci., 436, 94-97, 2011.

Mock, C. J., Bartlein, P. J., and Anderson, P. M.: Atmospheric circulation patterns and spatial climatic variations in Beringia, Int. J. Climatol., 18, 1085-1104, 1998.

Morley, D. W., Leng, M. J., Mackay, A. W., Sloane, H. J., Rioual, P., and Battarbee, R. W.: Cleaning of lake sediment samples for diatom oxygen isotope analysis, J. Paleolimnol., 31, 391-401, 2004.

Moschen, R., Lücke, A., and Schleser, G. H.: Sensitivity of biogenic silica oxygen isotopes to changes in surface water temperature and palaeoclimatology, Geophys. Res. Lett., 32, L07708, doi:10.1029/2004GL022167, 2005.

Moschen, R., Lücke, A., Parplies, J., Radtke, U., and Schleser, G. H.: Transfer and early diagenesis of biogenic silica oxygen isotope signals during settling and sedimentation of diatoms in a temperate freshwater lake (Lake Holzmaar, Germany), Geochim. Cosmochim. Ac., 70, 4367-4379, 2006.

Nolan, M. and Brigham-Grette, J.: Basic hydrology, limnology, and meteorology of modern Lake El'gygytgyn, Siberia, J. Paleolimnol., 37, 17-35, 2007.

Nolan, M., Cassano, E., and Cassano, J.: Synoptic climatology and recent climate trends at Lake El'gygytgyn, Clim. Past Discuss., 8, 1485-1522, doi:10.5194/cpd-8-1485-2012, 2012.

North-Greenland-Ice-Core-Project members: High-resolution record of Northern Hemisphere climate extending into the last interglacial period, Nature, 431, 147-151, 2004.

Nowaczyk, N. R., Minyuk, P., Melles, M., Brigham-Grette, J., Glushkova, O., Nolan, M., Lozhkin, A. V., Stetsenko, T. V., Andersen, P. M., and Forman, S. L.: Magnetostratigraphic results from impact crater Lake El'gygytgyn, northeastern Siberia; a $300 \mathrm{kyr}$ long high-resolution terrestrial palaeoclimatic record from the Arctic, Geophys. J. Int., 150, 109-126, 2002.

Nowaczyk, N. R., Melles, M., and Minyuk, P.: A revised age model for core PG1351 from Lake El'gygytgyn, Chukotka, based on magnetic susceptibility variations tuned to northern hemisphere insolation variations, J. Paleolimnol., 37, 65-76, 2007.

Petit, J. R., Jouzel, J., Raynaud, D., Barkov, N. I., Barnola, J. M., Basile, I., Bender, M., Chappellaz, J., Davis, M., Delaygue, G., Delmotte, M., Kotlyakov, V. M., Legrand, M., Lipenkov, V. Y., Lorius, C., Pepin, L., Ritz, C., Saltzman, E., and Stievenard, M.: Climate and atmospheric history of the past 420,000 years from the Vostok ice core, Antarctica, Nature, 399, 429-436, 1999.

Ragueneau, O., Tréguer, P., Leynaert, A., Anderson, R. F., Brzezinski, M. A., DeMaster, D. J., Dugdale, R. C., Dymond, J., Fischer, G., François, R., Heinze, C., Maier-Reimer, E., Martin-Jézéquel, V., Nelson, D. M., and Quéguiner, B.: A review of the Si cycle in the modern ocean: recent progress and missing gaps in the application of biogenic opal as a paleoproductivity proxy, Global Planet. Change, 26, 317-365, 2000.
Rosén, P., Vogel, H., Cunningham, L., Reuss, N., Conley, D., and Persson, P.: Fourier transform infrared spectroscopy, a new method for rapid determination of total organic and inorganic carbon and biogenic silica concentration in lake sediments, J. Paleolimnol., 43, 247-259, 2010.

Rozanski, K., Araguás-Araguás, L., and Gonfiantini, R.: Isotopic patterns in modern global precipitation, in: Climate Change in Continental Isotope Records, edited by: Swart, P., McKenzie, J. A., Lohmann, K. C., and Savin, S., Am. Geophys. Un., 1-36, 1993.

Schmidt, M., Botz, R., Stoffers, P., Anders, T., and Bohrmann, G.: Oxygen isotopes in marine diatoms: A comparative study of analytical techniques and new results on the isotope composition of recent marine diatoms, Geochim. Cosmochim. Ac., 61, 22752280, 1997.

Schmidt, M., Botz, R., Rickert, D., Bohrmann, G., Hall, S. R., and Mann, S.: Oxygen isotopes of marine diatoms and relations to opal-A maturation, Geochim. Cosmochim. Ac., 65, 201-211, 2001.

Seal, R. R. and Shanks, W. C.: Oxygen and hydrogen isotope systematics of Lake Baikal, Siberia: Implications for paleoclimate studies, Limnol. Oceanogr. 43, 1251-1261, 1998.

Serreze, M. C. and Barry, R. G.: Processes and impacts of Arctic amplification: A research synthesis, Global Planet. Change, 77, 85-96, 2011.

Serreze, M. C. and Francis, J.: The Arctic Amplification Debate, Climatic Change, 76, 241-264, 2006a.

Serreze, M. C. and Francis, J. A.: The Arctic on the fast track of change, Weather, 61, 65-69, 2006b.

Serreze, M. C., Walsh, J. E., Chapin, F. S., Osterkamp, T., Dyurgerov, M., Romanovsky, V., Oechel, W. C., Morison, J., Zhang, T., and Barry, R. G.: Observational Evidence of Recent Change in the Northern High-Latitude Environment, Climatic Change, 46, 159-207, 2000.

Sharp, Z. D.: A laser-based microanalytical method for the in situ determination of oxygen isotope ratios of silicates and oxides, Geochim. Cosmochim. Ac., 54, 1353-1357, 1990.

Shemesh, A., Charles, C. D., and Fairbanks, R. G.: Oxygen isotopes in biogenic silica: global changes in ocean temperature and isotopic composition, Science, 256, 1434-1436, 1992.

Shemesh, A., Burckle, L. H., and Hays, J. D.: Late Pleistocene oxygen isotope records of biogenic silica from the Atlantic sector of the Southern Ocean, Paleoceanography, 10, 179-196, 1995.

Shemesh, A., Rosqvist, G., Rietti-Shati, M., Rubensdotter, L., Bigler, C., Yam, R., and Karlén, W.: Holocene climatic change in Swedish Lapland inferred from an oxygen-isotope record of lacustrine biogenic silica, Holocene, 11, 447-454, 2001.

Snyder, J. A., Cherepanova, M. V., and Bryan, A.: Dynamic diatom response to changing climate $0-1.2 \mathrm{Ma}$ at Lake El'gygytgyn, far east Russian Arctic, Clim. Past Discuss., 8, 4601-4624, doi:10.5194/cpd-8-4601-2012, 2012.

Svendsen, J. I., Astakhov, V. I., Bolshiyanov, D. Y., Demidov, I., Dowdeswell, J. A., Gataullin, V., Hjort, C., Hubberten, H. W., Larsen, E., Mangerud, J. A. N., Melles, M., Möller, P., Saarnisto, M., and Siegert, M. J.: Maximum extent of the Eurasian ice sheets in the Barents and Kara Sea region during the Weichselian, Boreas, 28, 234-242, 1999. 
Svendsen, J. I., Alexanderson, H., Astakhov, V. I., Demidov, I., Dowdeswell, J. A., Funder, S., Gataullin, V., Henriksen, M., Hjort, C., Houmark-Nielsen, M., Hubberten, H. W., Ingólfsson, Ó., Jakobsson, M., Kjær, K. H., Larsen, E., Lokrantz, H., Lunkka, J. P., Lyså, A., Mangerud, J., Matiouchkov, A., Murray, A., Möller, P., Niessen, F., Nikolskaya, O., Polyak, L., Saarnisto, M., Siegert, C., Siegert, M. J., Spielhagen, R. F., and Stein, R.: Late Quaternary ice sheet history of northern Eurasia, Quaternary Sci. Rev., 23, 1229-1271, 2004.

Swann, G. E. A. and Leng, M. J.: A review of diatom $\delta^{18} \mathrm{O}$ in palaeoceanography, Quaternary Sci. Rev., 28, 384-398, 2009.

Swann, G. E. A. and Patwardhan, S. V.: Application of Fourier Transform Infrared Spectroscopy (FTIR) for assessing biogenic silica sample purity in geochemical analyses and palaeoenvironmental research, Clim. Past, 7, 65-74, doi:10.5194/cp-7-65-2011, 2011.

Swann, G. E. A., Mackay, A. W., Leng, M. J., and Demory, F.: Climatic change in Central Asia during MIS 3/2: a case study using biological responses from Lake Baikal, Global Planet. Change, 46, 235-253, 2005.

Swann, G. E. A., Leng, M. J., Sloane, H. J., and Maslin, M. A.: Isotope offsets in marine diatom $\delta^{18} \mathrm{O}$ over the last $200 \mathrm{ka}, \mathrm{J}$. Quaternary Sci., 23, 389-400, 2008.

Swann, G. E. A., Leng, M. J., Juschus, O., Melles, M., BrighamGrette, J., and Sloane, H. J.: A combined oxygen and silicon diatom isotope record of Late Quaternary change in Lake El'gygytgyn, North East Siberia, Quaternary Sci. Rev., 29, 774786, 2010.
Tapponnier, P. and Molnar, P.: Active Faulting and Cenozoic Tectonics of the Tien Shan, Mongolia, and Baykal Regions, J. Geophys. Res., 84, 3425-3459, 1979.

Thiede, J.: Quaternary Environments of the Eurasian North (QUEEN), Quaternary Sci. Rev., 23, 1225-1511, 2004.

Vogel, H., Rosén, P., Wagner, B., Melles, M., and Persson, P.: Fourier transform infrared spectroscopy, a new cost-effective tool for quantitative analysis of biogeochemical properties in long sediment records, J. Paleolimnol., 40, 689-702, 2008.

Wilkie, K. M. K., Chapligin, B., Meyer, H., Burns, S., Petsch, S., and Brigham-Grette, J.: Modern isotope hydrology and controls on $\delta \mathrm{D}$ of plant leaf waxes at Lake El'gygytgyn, NE Russia, Clim. Past Discuss., 8, 3719-3764, doi:10.5194/cpd-8-37192012, 2012.

Yancheva, G., Nowaczyk, N. R., Mingram, J., Dulski, P., Schettler, G., Negendank, J. F. W., Liu, J., Sigman, D. M., Peterson, L. C., and Haug, G. H.: Influence of the intertropical convergence zone on the East Asian monsoon, Nature, 445, 74-77, 2007.

Zachos, J., Pagani, M., Sloan, L., Thomas, E., and Billups, K.: Trends, Rhythms, and Aberrations in Global Climate 65 Ma to Present, Science, 292, 686-693, doi:10.1126/science.1059412, 2001. 